\title{
Expression of the progesterone receptor and progesterone- metabolising enzymes in the female and male human kidney
}

\author{
C Bumke-Vogt, V Bähr, S Diederich, S M Herrmann", \\ I Anagnostopoulos², W Oelkers and M Quinkler \\ Department of Endocrinology, Klinikum Benjamin Franklin, Freie Universität Berlin, Germany \\ ${ }^{1}$ Department of Clinical Pharmacology, Klinikum Benjamin Franklin, Freie Universität Berlin, Germany \\ ${ }^{2}$ Department of Pathology, Klinikum Benjamin Franklin, Freie Universität Berlin, Germany \\ (Requests for offprints should be addressed to C Bumke-Vogt, Department of Endocrinology, Universitätsklinikum Benjamin Franklin, Hindenburgdamm 30, \\ 12200 Berlin, Germany; Email: bumke-vogt@medizin.fu-berlin.de)
}

\begin{abstract}
Due to high binding affinity of progesterone to the human mineralocorticoid receptor (hMR), progesterone competes with the natural ligand aldosterone. In order to analyse how homeostasis can be maintained by mineralocorticoid function of aldosterone at the MR, especially in the presence of elevated progesterone concentrations during the luteal phase and pregnancy, we investigated protective mechanisms such as the decrease of free progesterone by additional binding sites and progesterone metabolism in renal cells. As a prerequisite for sequestration of progesterone by binding to the human progesterone receptor (hPR) we demonstrated the existence of hPR expression in female and male kidney cortex and medulla at the level of transcription and translation. We identified hPR RNA by sequencing the RT-PCR product and characterised the receptor by ligand binding and Scatchard plot analysis. The localisation of renal hPR was shown predominantly in individual epithelial cells of distal tubules by
\end{abstract}

immunohistology, and the isoform hPR-B was detected by Western blot analysis. As a precondition for renal progesterone metabolism, we investigated the expression of steroid-metabolising enzymes for conversion of progesterone to metabolites with lower affinity to the hMR. We identified the enzyme $17 \alpha$-hydroxylase for renal $17 \alpha$-hydroxylation of progesterone. For $20 \alpha$-reduction, different hydroxysteroid dehydrogenases (HSDs) such as $20 \alpha-H S D, 17 \beta-H S D$ type 5 (3 $\alpha$-HSD type 2$)$ and $3 \alpha-\mathrm{HSD}$ type 3 were found. Further, we detected the expression of $3 \beta-\mathrm{HSD}$ type 2 for $3 \beta$-reduction, $5 \alpha$-reductase (Red) type 1 for $5 \alpha$-reduction, and $5 \beta$-Red for $5 \beta$-reduction of progesterone in the human kidney. Therefore metabolism of progesterone and/or binding to hPR could reduce competition with aldosterone at the $\mathrm{MR}$ and enable the mineralocorticoid function.

Journal of Endocrinology (2002) 175, 349-364

\section{Introduction}

Progesterone is one of the main steroid hormones involved in the regulation of female reproductive function (Graham \& Clarke 1997). Its effects are mediated by the progesterone receptor (PR), a member of the nuclear receptor family of ligand-activated transcription factors (Tsai \& O'Malley 1994). Upon binding of progesterone to the ligand-binding domain (Williams \& Sigler 1998), the whole receptor protein undergoes conformational changes leading to dissociation from heat shock protein (hsp) such as hsp90 (Pratt \& Toft 1997). This enables dimerisation of receptor monomers and binding to hormone-responsive elements of DNA within the regulatory region of target genes (Beato et al. 1987). Transcription or suppression of the target gene depends on the context of promoter and the distribution of PR isoforms in target cells. Two isoforms of the PR have been described (Horwitz \& Alexander 1983): PR-B (933 amino acids) and PR-A (769 amino acids), the latter lacking $164 \mathrm{~N}$-terminal amino acids of PR-B. Both isoforms are expressed from the same gene by transcription from two alternative promoters and translation from two different start codons located in the transcript of the first exon (Kastner et al. 1990a). PR expression has been described in classical target organs like the uterus (Bergeron et al. 1988), ovary (Duffy \& Stouffer 1995), vagina (Batra \& Iosif 1985), breast (Horwitz \& McGuire 1975) and brain (pituitary gland and hypothalamus) (Kato et al. 1978). In endometrial stromal cells, progestins induce target genes encoding transforming growth factor- $\beta$ and insulin-like growth factor-binding protein (IGFBP)-1. The IGFBP-1 promoter is more 
strongly induced by PR-A than by PR-B (Gao et al. 2000). In uterine epithelia, the stimulating effect of progesterone on the expression of histidine decarboxylase is mediated by PR-B, as shown by experiments with knockout mice for PR-A, while PR-A seems to be essential for a progesterone activation of amphiregulin and calcitonin expression (Mulac-Jericevic et al. 2000). In the breast cancer cell line T-47D, progestins induce the expression of desmoplakin, CD59/protectin, FKPB51, and the $\mathrm{Na}^{+} / \mathrm{K}^{+}$-ATPase subunit $\alpha 1$. The latter is also found in normal breast tissue (Kester et al. 1997). In $\mathrm{T}-47 \mathrm{D}$, expression of the enzyme $11 \beta$-hydroxysteroid dehydrogenase (11 $\beta-\mathrm{HSD})$ type 2 is increased by progestins (Arcuri et al. 2000). For 11 $\beta-H S D$ type 2, co-localisation with the mineralocorticoid receptor (MR) has been demonstrated in normal and malignant human breast tissue (Sasano et al. 1997), where it could facilitate selective binding of aldosterone to $\mathrm{MR}$, as has been shown in the kidney (Edwards et al. 1988). McDonnell et al. (1994) described the possibility of a repression of MR transcriptional activity by ligand-activated PR-A via cross-talk of MR with this potent transdominant inhibitor competing for a common transcription factor or 'adaptor'.

The question whether the PR is also expressed in the human kidney is of special interest, since progesterone also binds with high affinity to the renal MR but confers only weak transcriptional activity. Hence progesterone is a strong MR antagonist (Rupprecht et al. 1993a, Myles \& Funder 1996). Geller et al. (2000) have described an agonistic progesterone function at the mutated $\mathrm{MR}_{\mathrm{L} 810}$, found in a family of patients with early onset of severe hypertension. Pregnant members developed preeclampsia caused by a normal increase of progesterone. To determine how homeostasis is maintained in late pregnancy, for example, when the plasma progesterone concentration can rise to $700 \mathrm{nM}$ (Johansson \& Jonasson 1971) with an aldosterone increase to $5.8 \mathrm{nM}$ (Nolten et al. 1978), we examined two mechanisms for avoiding excessive progesterone binding at the MR.

One explanation for the discrepancy of high progesterone concentration in the presence of wild-type MR and a still functioning renin-aldosterone system (Oelkers 1996) could be a competition of PR with MR for binding of progesterone in the kidney. Therefore we examined the expression of the human (h)PR in renal cortex and medulla of female (pre- and postmenopausal) and male origin. The possibility of high-specificity binding of progesterone to hPR in mineralocorticoid target cells could prevent antagonism or agonism of progesterone at the $\mathrm{MR}$ in the kidney.

Another mechanism for reducing progesterone binding to $\mathrm{MR}$ is the metabolic conversion of progesterone to derivatives with lower affinity to hMR. In renal cell fractions an effective metabolism of progesterone has been described as: $17 \alpha-\mathrm{OH}$ (hydroxy)-progesterone(P)
(23-32\%), 20 $\alpha-\mathrm{DH}$ (dehydro)-P (24-27\%), 17 $\alpha-\mathrm{OH}, 20 \alpha-$

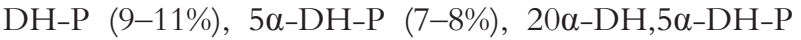
(5\%), 3 $3,5 \alpha-\mathrm{TH}$ (tetrahydro)-P (2-3\%), $20 \alpha-\mathrm{DH}, 3 \beta, 5 \alpha-$ TH-P $(2 \%), 3 \alpha, 5 \alpha-\mathrm{TH}-\mathrm{P}$ or $3 \beta, 5 \beta-\mathrm{TH}-\mathrm{P}(1-2 \%)$, and $5 \beta-\mathrm{DH}-\mathrm{P}(<1 \%)$ (total conversion of more than half of progesterone in the range of $1 \mathrm{nM}-1 \mu \mathrm{M}$ ) (Quinkler et al. 1999, 2001). These metabolites exhibit reduced affinity to the MR in comparison with progesterone: $7 \%$ for $17 \alpha-$ $\mathrm{OH}-\mathrm{P}, 11 \%$ for $20 \alpha-\mathrm{DH}-\mathrm{P}, 0 \cdot 2 \%$ for $17 \alpha-\mathrm{OH}, 20 \alpha-$ DH-P, $9 \%$ for $5 \alpha-\mathrm{DH}-\mathrm{P}, 0 \cdot 4 \%$ for $20 \alpha-\mathrm{DH}, 5 \alpha-\mathrm{DH}-\mathrm{P}$, $0 \cdot 5 \%$ for $3 \beta, 5 \alpha-\mathrm{TH}-\mathrm{P},<0 \cdot 1 \%$ for $20 \alpha-\mathrm{DH}, 3 \beta, 5 \alpha-\mathrm{TH}-$ $\mathrm{P},<0 \cdot 1 \%$ for $3 \alpha, 5 \alpha-\mathrm{TH}-\mathrm{P},<0 \cdot 1 \%$ for $3 \beta, 5 \beta-\mathrm{TH}-\mathrm{P}$, and $0.6 \%$ for $5 \beta-\mathrm{DH}-\mathrm{P}$ (Quinkler et al. 2002). Thus the following steroid-metabolising enzymes were examined for renal expression in female (premenopausal) and male kidney cortex and medulla: for $17 \alpha$-hydroxylation, $17 \alpha-$ hydroxylase/17,20-lyase (P450c17 or CYP17) (Chung

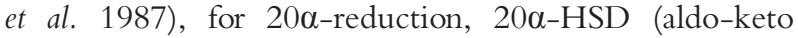
reductase AKR1C1) (Nishizawa et al. 2000), 3a-HSD type 3 (AKR1C2) (Shiraishi et al. 1998), prostaglandin F synthase (PGFS, AKR1C3) (Suzuki-Yamamoto et al. 1999), and 17ß-HSD type 5 (Dufort et al. 1999) with $20 \alpha$-HSD activity, for $5 \alpha$-reduction, both isoforms $5 \alpha$ reductase (Red) type 1 and type 2 (Andersson \& Russell 1990, Andersson et al. 1991), for $5 \beta$-reduction, $5 \beta$-Red (Kondo et al. 1994), and for 3 $\beta$-reduction, both isoforms $3 \beta-H S D$ type 1 and type 2 (Rheaume et al. 1991, Dumont et al. 1992).

\section{Materials and Methods}

\section{Human tissues and cell lines}

Kidney specimens were obtained from nephrectomies of female and male patients with renal carcinoma. Tissue not needed for histological diagnosis was separated into medulla and cortex specimens and immediately snap frozen in liquid nitrogen. Myometrium and endometrium were obtained from a hysterectomy of one postmenopausal patient with the indication of prolapsus uteri. The cell lines MCF7 (human breast adenocarcinoma cells), T-47D (human breast ductal carcinoma cells) and CV-1 (African green monkey kidney fibroblasts) were obtained from ATCC Cell Lines (Rockville, CA, USA).

\section{Cell culture}

CV-1 and MCF7 cells were cultured in Dulbecco's MEM (modified Eagle's medium) supplemented with 10\% fetal calf serum (FCS) and $100000 \mathrm{IU} / 1$ penicillin and $100 \mathrm{mg} / 1$ streptomycin. For culture of CV-1, $2.5 \mathrm{mg} / 1$ amphotericin $\mathrm{B}$ and for MCF7, $2 \mathrm{mM}$ glutamine were added. T-47D were maintained in RPMI 1640 medium with 10\% FCS, $100000 \mathrm{U} / 1$ penicillin and $100 \mathrm{mg} / 1$ streptomycin, $1 \mathrm{mM}$ sodium-pyruvate and 
$200 \mathrm{IU} / 1$ insulin. All materials used for cell culture were obtained from Seromed Biochrom, Berlin, Germany. Cells were grown in $70 \mathrm{~cm}^{2}$ flasks at $37^{\circ} \mathrm{C}$ under a $95 \%$ air-5\% $\mathrm{CO}_{2}$ humidified atmosphere.

\section{Preparation of cell and tissue homogenates and fractionation}

Cells were harvested with trypsin/EDTA $(0 \cdot 05 \% / 0 \cdot 02 \%)$, washed with PBS and lysed in ice-cold buffer containing potassium phosphate $\left(10 \mathrm{mM} \mathrm{K}_{2} \mathrm{HPO}_{4}\right.$ and $10 \mathrm{mM}$ $\mathrm{KH}_{2} \mathrm{PO}_{4}, 1.5 \mathrm{mM}$ EDTA, $3 \mathrm{mM} \mathrm{NaN}, 10 \%$ glycerol pH 7.5) (PENG buffer) (Pollow et al. 1989) supplemented with protease inhibitors obtained by dilution of Complete Mini protease inhibitors from Boehringer Mannheim, Mannheim, Germany. Three cycles of freezing in liquid nitrogen and thawing at $37^{\circ} \mathrm{C}$ or homogenisation with ten strokes in a cooled Potter homogeniser were used for lysis, and centrifugation at $4{ }^{\circ} \mathrm{C}(30 \mathrm{~min}, 15000 \mathrm{~g})$ for removal of debris and nuclei. Tissues of myometrium and endometrium were minced in 3 volumes $(\mathrm{w} / \mathrm{v})$ of ice-cold PENG buffer with an Ultra Turrax $(3 \times 2$ s) and homogenised as described above. Centrifugation at $4{ }^{\circ} \mathrm{C}$ $(10 \mathrm{~min}, 800 \mathrm{~g}$ ) sedimented the nuclear fraction. Cytosol was obtained by further centrifugation at $4{ }^{\circ} \mathrm{C}(30 \mathrm{~min}$, $15000 \mathrm{~g}$ ) as the supernatant fraction. Tissue homogenates of kidney cortex and medulla were prepared in 3 volumes of ice-cold lysis buffer containing $10 \mathrm{mM}$ sodium phosphate $\mathrm{pH} 7.4$ and $250 \mathrm{mM}$ sucrose (Monder \& Lakshmi 1989). Centrifugation at $4{ }^{\circ} \mathrm{C}(30 \mathrm{~min}, 750 \mathrm{~g})$ pelleted the nuclear fraction and $(60 \mathrm{~min}, 100000 \mathrm{~g}$ ) gave the cytosol fraction with soluble proteins in the supernatant. Proteins from the nuclear fraction were extracted with $0.4 \mathrm{M} \mathrm{KCl}$ in the presence of $1.5 \mathrm{mM}$ EDTA, $1 \mathrm{mM}$ dithiothreitol (DTT), $10 \mathrm{mM} \mathrm{Na} 2 \mathrm{MoO}_{4} \cdot 2 \mathrm{H}_{2} \mathrm{O}$, and $10 \%$ glycerol in lysis buffer. The protein contents of cytosols and nuclear fractions were analysed by using the Bio-Rad protein assay (Bio-Rad, Munich, Germany).

\section{Ligand binding assays and Scatchard plot analysis}

Promegestone (R5020) and [17 $\alpha$-methyl- $\left.{ }^{3} \mathrm{H}\right] \mathrm{R} 5020$ (NEN, Zaventem, Belgium) were used as high-specificity ligands for the progesterone receptor. [17 $\alpha$-methyl$\left.{ }^{3} \mathrm{H}\right] \mathrm{R} 5020$ with a specific activity of $80 \mathrm{Ci} / \mathrm{mmol}$ was diluted in ethanol for concentrations of $0 \cdot 05,0 \cdot 1,0 \cdot 2,0 \cdot 4$, $0 \cdot 8,1 \cdot 6,3 \cdot 2,6 \cdot 4$ and $12 \cdot 8 \mathrm{nM}$. Additionally a 200 -fold excess of cortisol for saturation of the corticoid-binding globulins and the glucocorticoid receptor (GR), and aldosterone for saturation of the MR were added. Rupprecht et al. (1993b) published affinities for aldosterone to the $\mathrm{MR}\left(K_{\mathrm{d}}=0.09 \mathrm{nM}\right.$ and $K_{\mathrm{i}}=0.08 \mathrm{nM}$ measured by competition), and for cortisol to the MR $\left(K_{\mathrm{i}}=0 \cdot 13 \mathrm{nM}\right)$ and to the GR $\left(K_{\mathrm{i}}=15 \mathrm{nM}\right)$. For each concentration a 100-fold excess of unlabelled R5020 was used to determine the extent of non-specific binding.
Steroids were evaporated and each dissolved in $100 \mu \mathrm{l}$ PENG buffer with $0.2 \%$ ethanol and kept on ice.

Cytosol fractions of cells (MCF7 and T-47D) and tissues (human renal cortex and medulla of postmenopausal patients) were pretreated with dextran-coated charcoal (DCC) $(0.5 \%$ DCC in PENG buffer) for removal of endogenous steroids by incubation at $4{ }^{\circ} \mathrm{C}$ for $1 \mathrm{~h}$. DCC with adsorbed steroids was sedimented by centrifugation at $4{ }^{\circ} \mathrm{C}(10 \mathrm{~min}, 15000 \mathrm{~g})$ and each $100 \mu \mathrm{l}$ aliquot of supernatant cytosol plus $100 \mu \mathrm{l}$ of dissolved steroids was incubated at $4{ }^{\circ} \mathrm{C}$ for $16 \mathrm{~h}$. Unbound steroids were removed following addition of $500 \mu \mathrm{l}$ 1\% DCC in PENG buffer by adsorption at $4{ }^{\circ} \mathrm{C}$ for $10 \mathrm{~min}$ and centrifugation at $4{ }^{\circ} \mathrm{C}$ $(10 \mathrm{~min}, 15000 \mathrm{~g})$. Aliquots $(600 \mu \mathrm{l})$ of the supernatant were transferred into scintillation vials with $10 \mathrm{ml}$ LSC Cocktail Ultima Gold (Packard, Dreieich, Germany) and counted for radioactivity. The binding parameters were calculated by linear regression analysis.

\section{Immunohistology}

Paraffin-embedded renal tissue specimens were retrieved from the files of the Department of Pathology at the Benjamin Franklin Clinic of the Free University of Berlin, Germany. They originated from the surroundings of renal cell carcinomas obtained in the course of nephrectomy. Myometrial tissue was obtained by hysterectomy. Sections of $4 \mu \mathrm{m}$ were cut, deparaffinised and subjected to an antigen-retrieval protocol to optimally visualise antigens in paraffin-embedded tissue. Tissue sections were immersed in citrate buffer $(10 \mathrm{mM}, \mathrm{pH} 6 \cdot 0)$ and cooked under high pressure for $5 \mathrm{~min}$. Sections were than incubated with the anti-PR IgG1 monoclonal antibody (clone PgR 636) in a dilution of 1:100. Bound antibody became visualised using the alkaline phosphatase-anti-alkaline phosphatase (APAAP) complex method and Fast Red as chromogen (Dako, Glostrup, Denmark).

\section{Western blotting}

Preparation of protein samples and immunoprecipitation of PR Cytosols or total protein preparations including nuclear extracts of cultured cells or tissues were used for immunoprecipitation of $\mathrm{PR}$ as described (Attia et al. 2000) with some modifications. Samples containing 500, 1000 and $5000 \mu \mathrm{g}$ protein were incubated for $1 \mathrm{~h}$ at $4{ }^{\circ} \mathrm{C}$ with $2-4 \mu \mathrm{g}$ rabbit polyclonal antibody $\mathrm{PR}(\mathrm{C} 20)$ sc539 (recognising a common region of PR-A and PR-B) obtained from Santa Cruz Biotechnology Inc. (Santa Cruz, CA, USA). Protein A-Sepharose (Amersham Pharmacia Biotech, Little Chalfont, Bucks, UK) in a mixture of packed swollen particles $1: 1$ in buffer A $(10 \mathrm{mM}$ Tris- $\mathrm{HCl} \mathrm{pH} 7.5$ with $1.5 \mathrm{mM}$ EDTA and $12 \mathrm{mM}$ monothioglycerol) was added $\left(100 \mu \mathrm{l}\right.$ per sample) and incubated for $1 \mathrm{~h}$ at $4{ }^{\circ} \mathrm{C}$. Immunocomplexes were precipitated by centrifugation 
$(1 \mathrm{~min}, 10000 \mathrm{~g}$ ) and each pellet washed twice with $500 \mu \mathrm{l}$ buffer A. Following resuspension in $20 \mu \mathrm{l} 2 \times \mathrm{SDS}$ loading buffer containing $215 \mathrm{mM}$ Tris $-\mathrm{HCl} \mathrm{pH} 6 \cdot 7$, $17 \cdot 4 \%$ glycerol, $5 \cdot 2 \%$ SDS, $8 \cdot 7 \% \beta$-mercaptoethanol and $0 \cdot 27 \%$ bromphenol blue, samples were denatured at $97{ }^{\circ} \mathrm{C}$ for 5 min. Protein A-Sepharose was pelleted by centrifugation $(1 \mathrm{~min}, 10000 \mathrm{~g}$ ) and the supernatant used for protein analysis.

SDS-PAGE, Western transfer blotting and immunodetection Polyacrylamide mini-gels for protein electrophoresis were prepared as described in the manual (Hoefer, San Francisco, CA, USA) with two layers of 8 and $5 \%$ polyacrylamide gels containing $0 \cdot 1 \%$ SDS respectively. Protein samples in SDS loading buffer and a prestained protein ladder (Bio-Rad) were separated during electrophoresis with $20 \mathrm{~mA} /$ gel for $1 \mathrm{~h}$ and proteins were blotted by electrotransfer with $400 \mathrm{~mA}$ for $2 \mathrm{~h}$ to PVDF membranes (Bio-Rad). Membranes were incubated overnight in a blocking solution containing $0.5 \%$ casein and $0 \cdot 1 \%$ Tween-20 in PBS (Vector Laboratories, Burlingame, CA, USA). Blocked membranes were incubated for $1 \mathrm{~h}$ at room temperature (RT) with primary antibody NCLPGR 312 (mouse monoclonal anti-hPR (PR-A and PR-B) IgG) (Novocastra, Newcastle, UK) diluted 1:1000 in blocking solution and, following extensive washing, for $1 \mathrm{~h}$ at RT with the secondary antibody goat anti-mouse IgG conjugated to peroxidase (Sigma, Deisenhofen, Germany), diluted $1: 4000$ in blocking solution. Chemiluminescence of the peroxidase reaction was detected by ECL or ECL Plus (Amersham Pharmacia Biotech). PVDF membranes were stripped for $30 \mathrm{~min}$ at $50{ }^{\circ} \mathrm{C}$ in $62.5 \mathrm{mM}$ Tris- $\mathrm{HCl}$ pH $6.7, \quad 100 \mathrm{mM}$ $\beta$-mercaptoethanol, 2\% SDS, blocked and reincubated with NCL-PGR 312, followed by a different secondary antibody (biotinylated anti-mouse $\operatorname{IgG}$ diluted 1:300) and horseradish peroxidase-streptavidin diluted 1:500 (Vector).

\section{Preparation of RNA for gene expression analysis}

RNAs from tissues (150-250 mg snap-frozen kidney cortex and medulla specimens) and from cultured cells $\left(10^{6}-10^{7}\right.$ cells of MCF7 or CV-1) were isolated immediately after thawing of tissues or directly after harvesting of cells respectively with the RNeasy Kit (Qiagen, Hilden, Germany) including an on-column DNase digestion with the RNase-free DNase set also provided by Qiagen. The concentration and quality of RNA was determined photometrically $(260 / 280 \mathrm{~nm})$.

\section{RT-PCR}

RNA $(2.5 \mu \mathrm{g})$ was annealed with random hexamer primers, $15 \mu \mathrm{g} / 45 \mu \mathrm{l}$ incubation volume, for $10 \mathrm{~min}$ at $70{ }^{\circ} \mathrm{C}$. First-strand reverse transcription was performed in $100 \mu \mathrm{l}$ mixtures with $1000 \mathrm{U}$ RT II Superscript polymerase in the presence of $40 \mathrm{U}$ RNase inhibitor, $1 \mu \mathrm{mol}$ DTT, $50 \mathrm{nmol}$ dATP, $50 \mathrm{nmol} \mathrm{dGTP,} 50 \mathrm{nmol}$ dCTP, $50 \mathrm{nmol}$ dTTP in first-strand buffer for $1 \mathrm{~h}$ at $37^{\circ} \mathrm{C}$ followed by denaturation for $5 \mathrm{~min}$ at $95^{\circ} \mathrm{C}$. All supplements were obtained from Gibco BRL (Karlsruhe, Germany). Specific PCRs with synthesised cDNA templates (transcribed from 40 ng RNA) were carried out in amplification mixtures of $25 \mu \mathrm{l}$ containing $20 \mathrm{mM}$ Tris- $\mathrm{HCl} \mathrm{pH} 8.4,50 \mathrm{mM} \mathrm{KCl}, 1.5 \mathrm{mM} \mathrm{MgCl}_{2}$, and $0.2 \mathrm{mM}$ each of dATP, dCTP, dGTP, dTTP using $1 \mathrm{U}$ Taq DNA polymerase (Gibco BRL) and $12 \mathrm{pmol}$ specific sense and antisense primers (Tib Molbiol, Berlin, Germany) listed in Table 1.

PCRs were performed with an initial step of denaturation for 2 min at $94{ }^{\circ} \mathrm{C}$ and were run for 35 cycles with denaturation for $45 \mathrm{~s}$ at $94{ }^{\circ} \mathrm{C}$, annealing for $1 \mathrm{~min}$ at the thermodynamic melting temperature of the specific primer pair (Table 1), and extension for $90 \mathrm{~s}$ at $72{ }^{\circ} \mathrm{C}$ followed by a final extension for $10 \mathrm{~min}$ at $68^{\circ} \mathrm{C}$. Amplicons were resolved by electrophoresis in 1\% agarose gels stained with ethidium bromide. The size and quantity of PCR products were approximated by comparison with a $1 \mathrm{~kb}$ Plus-DNA ladder and DNA low-mass ladder (Gibco BRL). PCR products of expected size were re-extracted from agarose gels (QIAquic gel extraction kit; Qiagen) for direct sequencing. Each sample was sequenced twice with the specific sense and antisense primers (Table 1) respectively using an automated sequencing device (ABI Prism 377; Perkin-Elmer, Überlingen, Germany), as described previously by Herrmann et al. (2001). Sequences were identified by blast search GenBank analysis.

\section{hPR-specific high-stringency PCR}

The conditions of hPR-specific RT-PCR were similar to those described (Misao et al. 1998) with 35 instead of 25 cycles using an annealing temperature of $55^{\circ} \mathrm{C}$ for the primer pair hPR sense and hPR antisense (Table 1). We investigated cDNAs from tissue specimens of kidney cortex and medulla of a premenopausal, a postmenopausal, and a male patient. The PR-expressing breast carcinoma cell line MCF7 was used as positive control. The vector pRShMR which contains the complete coding sequence (CDS) for the hMR (Arriza et al. 1987), kindly provided by $\mathrm{R}$ Evans, was used as negative control for the hPR-specific PCR.

\section{High-stringency PCRs specific for progesterone-metabolising enzymes}

Specific primers were designed according to published sequences of steroid-converting enzymes and PCRs were performed with 35 cycles using primer pair-specific annealing temperatures as summarised in Table 1. 


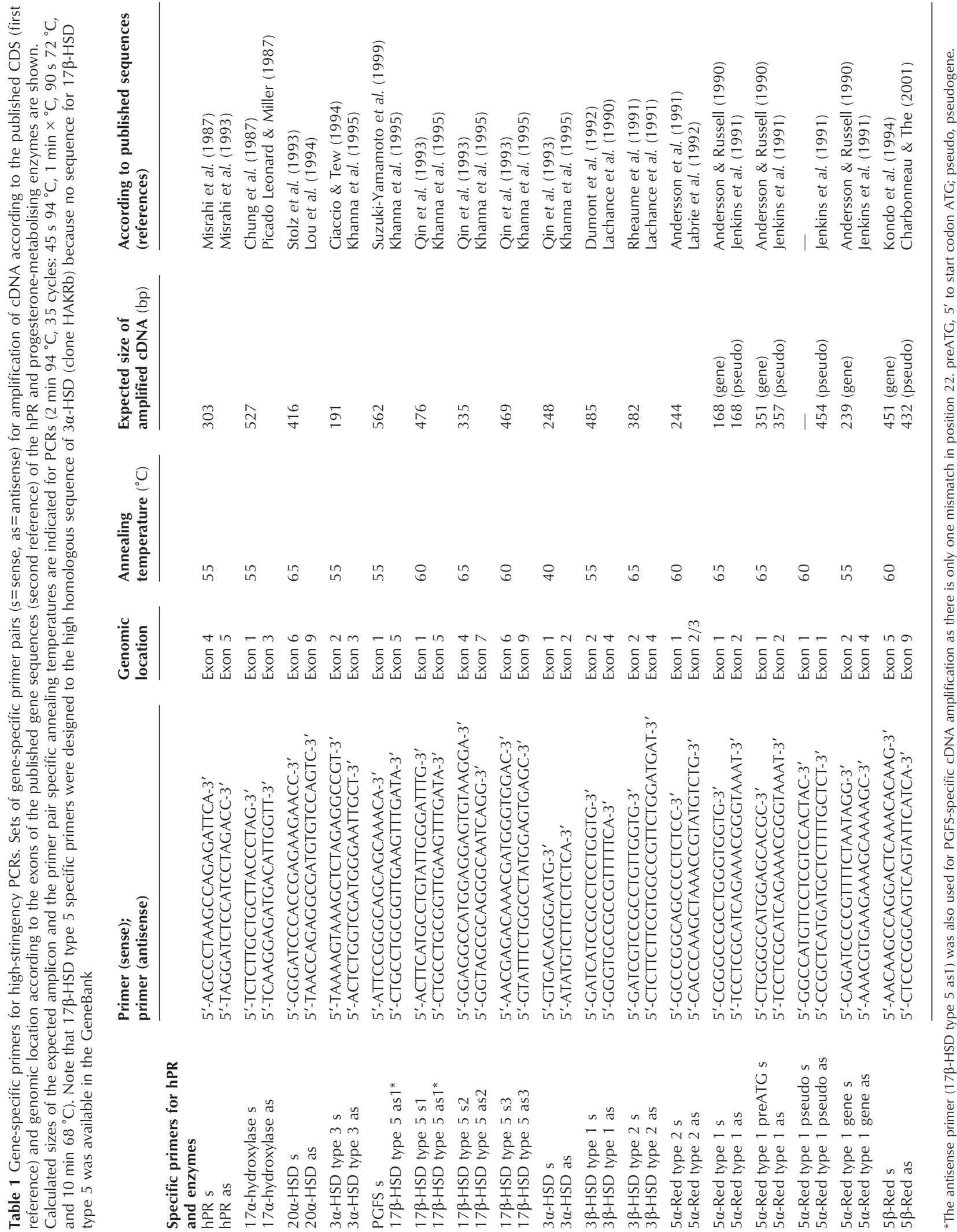


Table 2 Comparison of ligand binding characteristics. Scatchard plot analyses were performed with $\left[{ }^{3} \mathrm{H}\right] \mathrm{R} 5020$ using steroid-depleted cytosol fractions from tissue specimens of human kidney cortex and medulla (postmenopausal), myometrium (postmenopausal) as classical target tissue control and from hPR-expressing breast carcinoma cells MCF7 and T-47D

\begin{tabular}{|c|c|c|}
\hline \multirow[b]{2}{*}{ Tissues and cells } & $\boldsymbol{K}_{\mathbf{d}}(\mathrm{nM})$ & $\mathbf{B}_{\max }(\mathrm{fmol} / \mathrm{mg}$ protein $)$ \\
\hline & & \\
\hline Kidney cortex & $0 \cdot 76$ & 7 \\
\hline Kidney medulla & $0 \cdot 86$ & 17 \\
\hline Myometrium & $0 \cdot 98$ & 213 \\
\hline MCF7 & $0 \cdot 57$ & 43 \\
\hline $\mathrm{T}-47 \mathrm{D}$ & $0 \cdot 44$ & 347 \\
\hline
\end{tabular}

$K_{\mathrm{d}}=$ dissociation constant for specific binding of promegestone (R5020) to the receptor ( $\mathrm{hPR}$ ); $\mathrm{B}_{\max }=$ maximum concentration of available binding sites (calculated using the linear regression method).

Templates for enzyme expression analyses were cDNAs from female (premenopausal) and male kidney samples and from CV-1 monkey kidney cells as control. Additionally cDNA templates from human adrenals and testes, kindly provided by $\mathrm{W}$ Arlt, were used as positive controls for steroid-metabolising enzyme expression.

\section{Results}

Characterisation of the $h P R$ by binding of promegestone (R5020)

Scatchard plot analysis was performed using steroid depleted cytosol fractions from renal cortex and medulla as well as from myometrium (target tissue control). Additional positive controls were MCF7 and T-47D breast carcinoma cells, the latter overexpressing hPR-A. Specific binding of promegestone (R5020) as a highly specific ligand for the PR was found in kidney cortex and medulla specimens as well as in all controls. The binding affinities, characterised by their dissociation constant $\left(K_{\mathrm{d}}\right.$ values) calculated by linear regression analysis, were in the same range $(0.44-0.98 \mathrm{nM})$ for all samples (Table 2). Therefore the existence of the same kind of receptor in both kidney specimens and the progesterone target tissue myometrium as well as in hPR-expressing cells could be assumed. The amount of R5020-specific binding protein $\left(\mathrm{B}_{\max }\right)$ in the kidney $(7-17 \mathrm{fmol} / \mathrm{mg}$ protein) was less than $10 \%$ compared with the target tissue myometrium (213 fmol/mg protein). $\mathrm{B}_{\max }$ in MCF7 cells was $43 \mathrm{fmol} / \mathrm{mg}$ protein and in T-47D cells $347 \mathrm{fmol} / \mathrm{mg}$ protein (Table 2).

\section{Localisation of hPR in human kidneys by immunohistology}

In tissue sections of female postmenopausal (Fig. 1A and B), premenopausal (Fig. 1C and D) and male (Fig. 1F) human kidneys and of myometrium (Fig. 1E) used as positive control, hPR was detected as nuclear staining following treatment with the antibody PgR 636, APAAP and Fast Red chromogen. A high percentage of myometrial smooth muscle cells stained positively for hPR (Fig. 1E). Labelling for hPR was also detected in kidney specimens. Positive immunodetections of hPR were found predominantly in some individual epithelial cells of distal tubules in female (Fig. 1A-C) and male (Fig. 1F), in single podocytes of glomeruli in postmenopausal (Fig. 1B), premenopausal (Fig. 1D), and male (Fig. 1F), in parietal cells in premenopausal (Fig. 1D) and in few interstitial cells of investigated renal tissues. The cytoplasmic staining (Fig. 1D and F) is probably not PR-specific but artefactual (reaction of anti-alkaline phosphatase, used in APAAP, with the renal alkaline phosphatase).

\section{$h P R-B$ is synthesised in female and male kidneys}

Western blots of protein fractions prepared by immunoprecipitation of hPR gave chemiluminescent signals in human male and female kidney samples as a single band, corresponding to the middle band of the triplet for PR-B in cytoplasm of T-47D used as control $(114,117$, $120 \mathrm{kDa}$ ) (Sheridan et al. 1989). This $117 \mathrm{kDa}$ protein band was hardly detectable in a sample of cytosol from male kidney cortex with $200 \mu \mathrm{g}$ protein content without immunoprecipitation of hPR, but the immunoprecipitates from cytosol aliquots with 5000, 1000 and $500 \mu \mathrm{g}$ protein gave clear concentration-dependent chemiluminescent signals (Fig. 2A). This dependence on protein concentration used for immunoprecipitation was also found in total protein extracts from female kidney cortex and medulla (Fig. 2B). Smears of chemiluminescent signals in the range of slightly higher to lower size of PR-A (detectable in all samples) could not be identified as PR-A as in T-47D. After membrane stripping and reincubation with the identical first antibody, NCL-PGR 312, and a different second antibody (biotinylated anti-mouse $\operatorname{IgG}$ followed by horseradish peroxidase-streptavidin detection), chemiluminescence did not appear directly at the position of PR-A (compared with T-47D), but there were strong signals at the position of PR-B, besides non-specific bands smaller than PR-B and PR-A (Fig. 2A and B, lower panel). Therefore, only the synthesis of PR-B could be clearly shown in male and female kidney specimens.

\section{hPR-gene expression in the kidney}

The transcription of the hPR-gene analysed by RT-PCR was found in all of our kidney samples (Fig. 3). From cDNAs of renal cortex and medulla from premenopausal, postmenopausal and male patients, PCR products of $303 \mathrm{bp}$ were amplified with the hPR-specific primer pair (Table 1), similar to the positive control MCF7 (PR-expressing cell line). The negative control did not give any DNA staining with ethidium bromide. In 


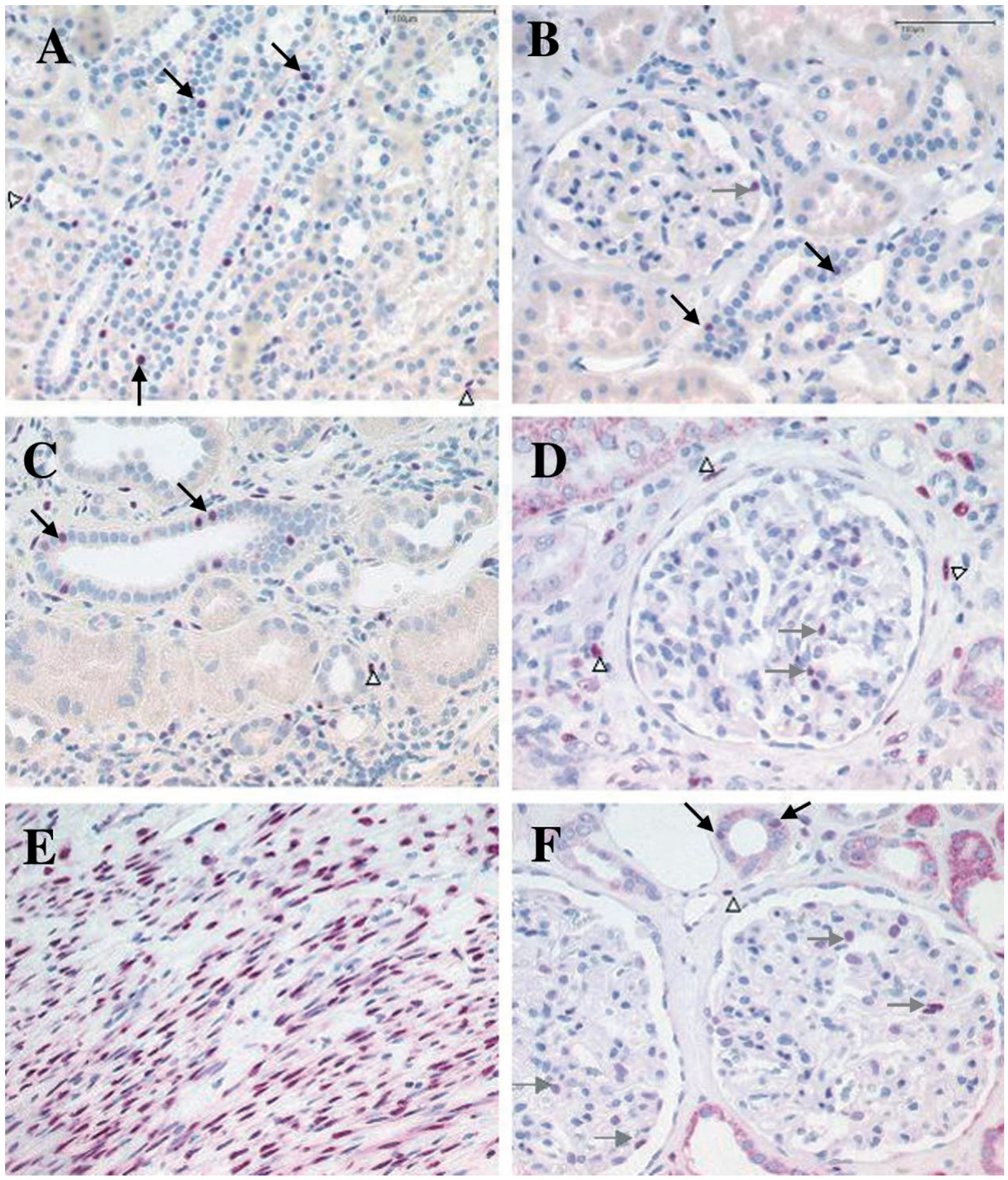

Figure 1 Immunohistological demonstration of PR expression in human kidney tissues. Immunohistological visualisation of hPR was performed on paraffin-embedded renal sections $(4 \mu \mathrm{m})$ using PgR $636(1: 100)$ and APAAP complex formation with Fast Red chromogen. Demonstration of PR-positive cells in the epithelia of distal tubules (black arrows), glomeruli (grey arrows), and interstitium (white arrow-heads) in kidneys of different origin: postmenopausal (A, B), premenopausal (C, D), male (F) human kidney. Control staining for hPR was performed on myometrium (E). 


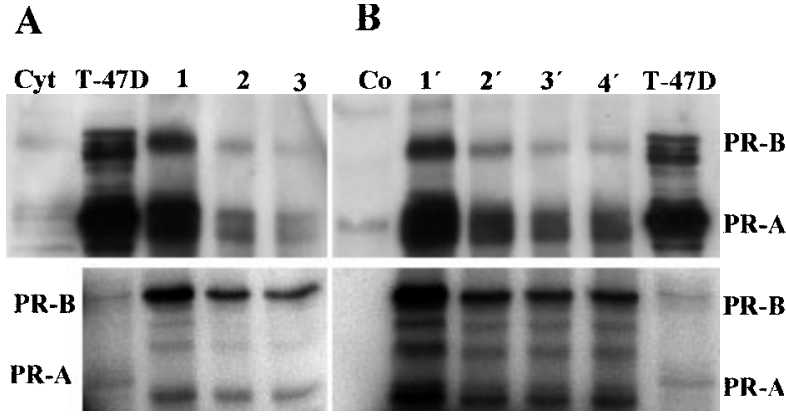

Figure 2 Western blot and immunodetection with NCL-PGR 312. (A) SDS-PAGE of $200 \mu \mathrm{g}$ total protein from cytosol (Cyt) of male kidney cortex without immunoprecipitation, of $10 \mu \mathrm{g}$ total protein from T-47D cells overexpressing PR-A as positive control, and immunoprecipitates obtained with $\mathrm{PR}(\mathrm{C} 20)$ sc539 rabbit polyclonal IgG from $5000 \mu \mathrm{g}$ (lane 1), $1000 \mu \mathrm{g}$ (lane 2), $500 \mu \mathrm{g}$ (lane 3) protein in cytosol. (B) SDS-PAGE of PR(C20) sc539 under conditions of immunoprecipitation without renal proteins as negative control $(\mathrm{Co})$, immunoprecipitates from $5000 \mu \mathrm{g}$ (lane $1^{\prime}$ ), $1000 \mu \mathrm{g}$ (lane 2'), $500 \mu \mathrm{g}$ (lane 3') total protein extract (cytosolic and nuclear proteins) of female kidney cortex and from $500 \mu \mathrm{g}$ (lane $4^{\prime}$ ) of female kidney medulla, and $10 \mu \mathrm{g}$ T-47D protein containing PR-A and PR-B as positive control. (A, B) Proteins were transferred to PVDF membranes and hPR immunodetected with NCL-PGR 312 mouse monoclonal anti-hPR IgG (1:1000) and goat anti-mouse IgG conjugated to peroxidase $(1: 4000)$ and visualised by chemiluminescence in the upper panel. There are concentration-dependent specific chemiluminescent signals as a single band at the position of PR-B in all kidney samples corresponding to the middle band in the triplet of PR-B $(117 \mathrm{kDa})$ visible in T-47D, which was not detected in the negative control. A smear of chemiluminescence around the expected size of PR-A was found in all samples, but without concentration at the position of the PR-A-specific band as in the track of T-47D. There was a faint signal in the negative control evoked by the immunoprecipitating antibody itself as well. In the lower panel only PR-B could be detected after stripping of the membranes (A) and (B) and immunodetection with NCL-PGR 312 as well followed by biotinylated anti-mouse IgG and horseradish peroxidasestreptavidin. Chemiluminescent signals at positions smaller than PR-B and PR-A seem to be non-specific for PR.

addition to 35 cycles of PCR, lower cycle numbers were performed. Staining of specific PCR products was obtained from MCF7 cDNA after 25 cycles and from kidney samples after 30 cycles of PCR (data not shown). Direct sequencing (forward with the hPR sense primer and reverse with the hPR antisense primer) of the PCR product from the premenopausal kidney cortex revealed $100 \%$ sequence homology (Table 3) according to the published sequence (Misrahi et al. 1987). This confirmed the identity of the hPR-specific RT-PCR product in the human kidney.

\section{Expression of different enzymes for progesterone metabolism}

PCRs for steroid-metabolising enzymes were performed with different specific primer pairs (Table 1) tested with cDNA templates from human adrenals and testes as

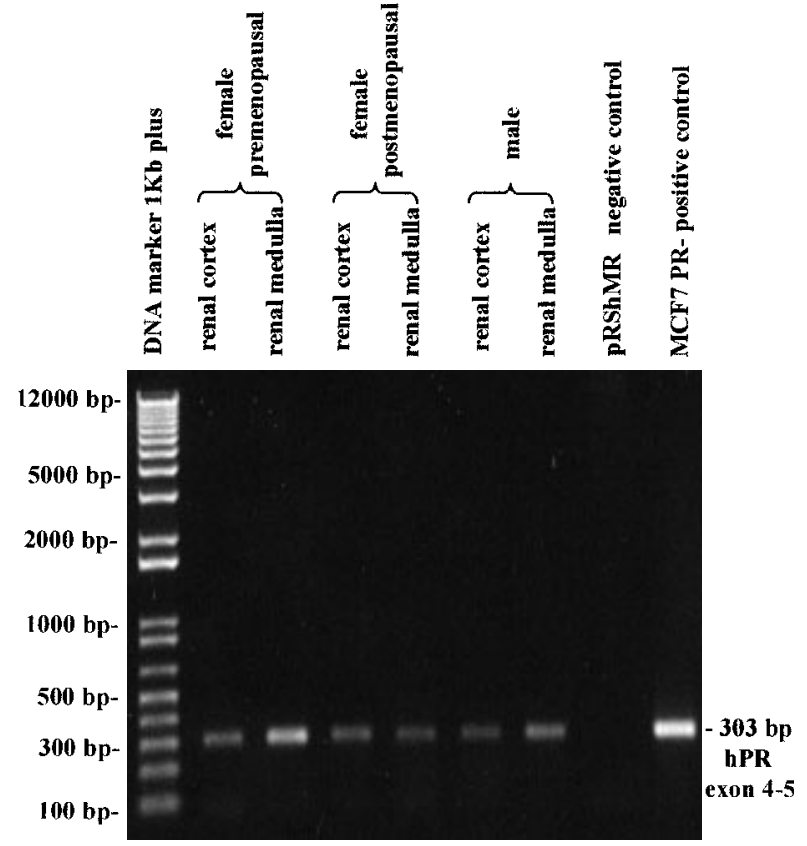

Figure 3 RT-PCR analysis for the expression of hPR. CDNAs obtained by reverse transcription of RNA from kidney cortex and medulla specimens of female (pre- and postmenopausal) and male origin and from MCF7 cells expressing the hPR as positive control were amplified by high-stringency hPR-specific PCR. pRShMR was used as template for the negative control. PCR products were separated on a $1 \%$ agarose gel with a $1 \mathrm{~kb}$-Plus DNA ladder for sizing. Staining with ethidium bromide visualised the DNA marker (100-12 $000 \mathrm{bp}$ ) and single bands of $303 \mathrm{bp}$ amplicons specific for hPR (exon 4-5) from all kidney specimens and MCF7. pRShMR was not amplified by hPR-specific PCR.

positive controls (Fig. 4). Amplicons of primer-specific calculated sizes (Table 1) were obtained for $17 \alpha-$ hydroxylase (527 bp), 20 $\alpha$-HSD (416 bp), 3a-HSD type 3 (191 bp), 3a-HSD type 2 (562 bp), 17 $\beta$-HSD type 5 (335 bp), 3 $\beta$-HSD type 2 (382 bp) and $5 \alpha$-Red type 1 $(239 \mathrm{bp})$ from both adrenals and testes. PCR products for $5 \alpha$-Red type 2 (244 bp) and 5 $\beta$-Red (451 bp) were synthesised only from testes but not from adrenals, and for $3 \beta-H S D$ type 1 amplification could not be detected from adrenals (Fig. 4) or from testes (data not shown). PCRs with cDNA templates from human kidney cortex and medulla (premenopausal and male) and from the monkey kidney cell line CV-1 gave the following results.

17 $\alpha$-hydroxylase $(\mathbf{P} 450 \mathbf{c 1 7}=\mathbf{C Y P} 17) \quad$ The renal expression of 17 $\alpha$-hydroxylase (capable of hydroxylation at the angular C17 of the pregnane body) was analysed by RT-PCR slightly modified from the method described by Jose et al. (1999). Amplification of the expected PCR product of $527 \mathrm{bp}$ was detected from cDNAs of all kidney samples as well as from CV-1 (Fig. 5A). Sequencing of the re-extracted and reamplified $527 \mathrm{bp}$ PCR product 
Table 3 Renal expression of PR and progesterone-metabolising enzymes. Expression analyses were performed from human kidney specimens (cortex and medulla) by RT-PCR and direct sequencing of specific amplicons from samples of one premenopausal patient. Detection is indicated by + and the homologies of the PCR product to the published sequences are given as percentage. - is used if expression (e.g. of isoenzymes) was not detected in the human kidney specimens used for analysis

\begin{tabular}{|c|c|c|c|c|}
\hline \multirow{3}{*}{$\begin{array}{l}\text { Analysed receptor } \\
\text { and enzymes } \\
\text { hPR }\end{array}$} & $\begin{array}{l}\text { Amplification } \\
\text { of cDNA (bp) }\end{array}$ & $\begin{array}{l}\text { Found in the } \\
\text { human kidney }\end{array}$ & $\begin{array}{l}\text { Homology to } \\
\text { published sequences }(\%)\end{array}$ & \multirow[t]{2}{*}{ References } \\
\hline & & & & \\
\hline & 303 & + & 100 & Misrahi et al. (1987) \\
\hline $17 \alpha$-hydroxylase (=CYP17) & 527 & + & $\begin{array}{l}100 \\
99 \cdot 8\end{array}$ & $\begin{array}{l}\text { Chung et al. (1987) } \\
\text { Picado Leonard \& Miller (1987) }\end{array}$ \\
\hline$(=\mathrm{DD} 1, \mathrm{AKR} 1 \mathrm{C} 1)$ & 416 & + & 100 & Nishizawa et al. (2000) \\
\hline $3 \alpha$-HSD type 3 (=DD2, AKR1C2) & 191 & + & 100 & Shiraishi et al. (1998) \\
\hline PGFS ( $=3 \alpha-\mathrm{HSD}$ type $2, \mathrm{AKR} 1 \mathrm{C} 3$ ) & 562 & + & $99 \cdot 8$ & Suzuki-Yamamoto et al. (1999) \\
\hline $\begin{array}{l}17 \beta \text {-HSD type } 5 \text { amplicon } 1 \\
17 \beta \text {-HSD type } 5 \text { amplicon } 2 \\
17 \beta \text {-HSD type } 5 \text { amplicon } 3 \\
17 \beta \text {-HSD } / 3 \alpha \text {-HSD type } 2\end{array}$ & $\begin{array}{l}476 \\
335 \\
469\end{array}$ & $\begin{array}{l}+ \\
+ \\
+\end{array}$ & $\begin{array}{l}99 \cdot 6 \\
99 \cdot 1 \\
99 \cdot 5 \text { for complete CDS } \\
99 \cdot 8 \text { for complete CDS }\end{array}$ & $\begin{array}{l}\text { Qin et al. }(1993)^{*} \\
\text { Qin et al. }(1993)^{*} \\
\text { Qin et al. }(1993)^{*} \\
\text { Lin et al. (1997) }\end{array}$ \\
\hline $3 \alpha-\mathrm{HSD}(=\mathrm{HAKRb})$ & - & - & - & Qin et al. (1993) \\
\hline $\begin{array}{l}3 \beta \text {-HSD type } 1 \\
3 \beta \text {-HSD type } 2\end{array}$ & - & $\begin{array}{l}- \\
+\end{array}$ & - & $\begin{array}{l}\text { Dumont et al. (1992) } \\
\text { Rheaume et al. (1991) }\end{array}$ \\
\hline $5 \alpha$-Red type 2 & & - & - & Andersson et al. (1991) \\
\hline $5 \alpha$-Red type 1 & $\begin{array}{l}168 \text { (gene) } \\
168 \text { (pseudo) }\end{array}$ & $\begin{array}{l}+ \\
+\end{array}$ & $\begin{array}{l}95 \cdot 0 \text { female and } 99 \cdot 0 \text { male } \\
99 \cdot 4\end{array}$ & $\begin{array}{l}\text { Andersson \& Russell (1990) } \\
\text { Jenkins et al. (1991) }\end{array}$ \\
\hline $5 \alpha$-Red type 1 & $\begin{array}{l}351 \text { (gene) } \\
357 \text { (pseudo) }\end{array}$ & $\begin{array}{l}+ \\
+\end{array}$ & $\begin{array}{l}99 \cdot 0 \\
100\end{array}$ & $\begin{array}{l}\text { Andersson \& Russell (1990) } \\
\text { Jenkins et al. (1991) }\end{array}$ \\
\hline $5 \alpha$-Red type 1 pseudogene & 454 (pseudo) & + & 100 & Jenkins et al. (1991) \\
\hline $5 \alpha$-Red type 1 gene & 239 (gene) & + & 100 & Andersson \& Russell (1990) \\
\hline $5 \beta$-Red & $\begin{array}{l}451 \text { (gene) } \\
432 \text { (pseudo) }\end{array}$ & $\begin{array}{l}+ \\
+\end{array}$ & $\begin{array}{l}89 \cdot 0 \\
99 \cdot 0\end{array}$ & $\begin{array}{l}\text { Kondo et al. (1994) } \\
\text { Charbonneau \& The (2001) }\end{array}$ \\
\hline
\end{tabular}

*Note that the sequence published for HAKRb was supposed to be $3 \alpha$-HSD type 2, highly homologous to $17 \beta$-HSD type 5 (an enzyme with only two amino acid exchanges). pseudo, pseudogene.

from the premenopausal kidney cortex revealed 100\% homology to the corresponding part of the CYP17 sequence (Chung et al. 1987) (Table 3).

For all investigated HSDs and reductases only those PCR products from premenopausal kidney of the same patient are shown in Fig. 5B and C. The same amplicons were used for sequencing.

AKR1C1 (=20a-HSD, dihydrodiol dehydrogenase 1 (DD1)) The expression of 20 $\alpha$-HSD (aldo-keto reductase AKR1C1) (Nishizawa et al. 2000) was analysed by sequencing a specific PCR product amplified with highly specific primers (Table 1) for the AKR1C1 sequence containing mismatches to sequences of other members of the AKR1C family. Amplification of the expected $416 \mathrm{bp}$ product appeared in all human kidney samples as well as in CV-1 monkey kidney cells. One hundred per cent homology to the published sequence of $20 \alpha-\mathrm{HSD}$ was found (Table 3).

AKR1C2 (=3 $\alpha$-HSD type 3, DD2, bile acid binding protein BABP) Analysing the expression of the enzyme $3 \alpha-\mathrm{HSD}$ type 3 (=AKR1C2, DD2, BABP), the sequence of a PCR product amplified with primers containing unique nucleotides for $3 \alpha-\mathrm{HSD}$ type 3 at their $3^{\prime}$-ends (Table 1), revealed $100 \%$ homology to the sequence of 3a-HSD type 3 (Shiraishi et al. 1998) (Table 3).

AKR1C3 (=PGFS, 3a-HSD type 2) The expression of the enzyme PGFS (=AKR1C3) with a sequence (SuzukiYamamoto et al. 1999) identical with AKR1C3, which was reported to be 3a-HSD type 2 (Khanna et al. 1995), was investigated by sequencing a PCR product obtained with a PGFS-specific sense primer (Table 1) and the antisense primer (17 $\beta$-HSD type 5 as $1 \star)$, used because of high homology to the corresponding sequence of PGFS. For the 562 bp product, $99 \cdot 8 \%$ homology was found to the PGFS sequence (Table 3) with G instead of A (312th nucleotide (nt) of the CDS), which does not alter the amino acid sequence.

17ß-HSD type 5 similar to $3 \alpha-H S D$ (clone of human aldo-keto reductase $\mathbf{b}$ (HAKRb)) As the human enzyme $17 \beta-H S D$ type 5 possesses a high $20 \alpha-H S D$ activity that inactivates progesterone to $20 \alpha-\mathrm{DH}-\mathrm{P}$ (Dufort et al. 1999), we analysed the expression of $17 \alpha-H S D$ type 5 in 

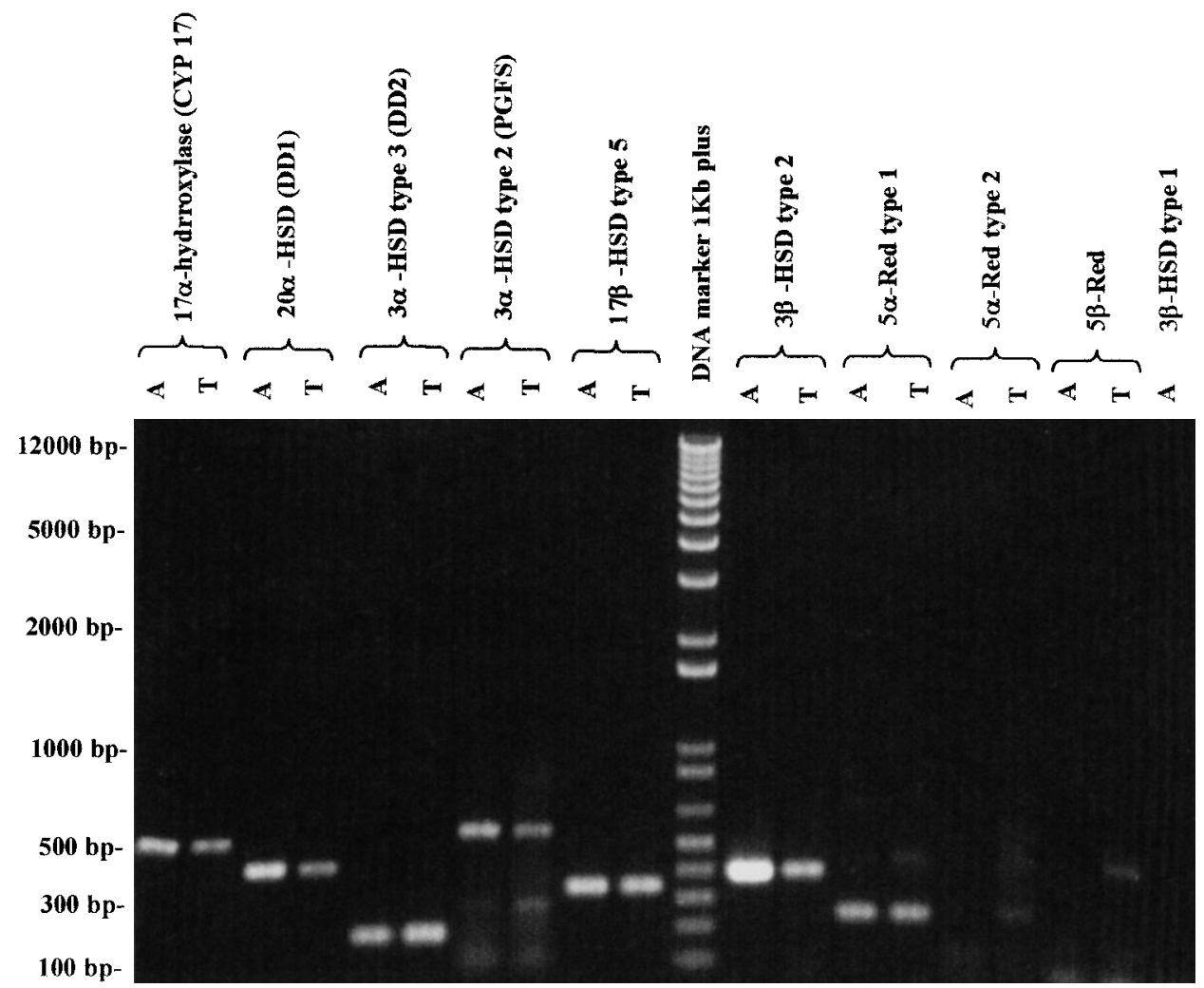

Figure 4 High-stringency PCR controls for steroid-metabolising enzymes. cDNAs from adrenals (A) and testes $(\mathrm{T})$ as positive controls were amplified with specific primer pairs for different steroid-metabolising enzymes. PCR products of expected size of 527 bp for $17 \alpha$-hydroxylase, 416 bp for $20 \alpha$-HSD, 191 bp for $3 \alpha$-HSD type 3,562 bp for $3 \alpha$-HSD type 2,335 bp for $17 \beta$-HSD type 5,382 bp for $3 \beta$-HSD type 2 , and 239 bp for $5 \alpha$-Red type 1 were obtained from both adrenals and testes. Amplifications of $244 \mathrm{bp}$ for $5 \alpha$-Red type 2 and 451 bp for $5 \beta$-Red were achieved only from testes, and a specific amplicon for $3 \beta$-HSD type 1 could not be shown.

the human kidney. Amplifications of three overlapping parts originating from exon $1-5,4-7$ and 6-9 covering nearly the complete CDS (Table 1) were performed with primers according to the homologous sequence of $3 \alpha-$ HSD clone HAKRb (Qin et al. 1993) encoding an enzyme differing only in the 75 th and 175 th amino acid from $17 \beta$-HSD type 5 . All three expected PCR products of 476, 335 and $469 \mathrm{bp}$ (Table 3) were amplified from cDNAs of all human kidney samples and CV-1 cells as well, the latter missing only the PCR product of the last segment. This suggests differences in human and monkey sequences located $3^{\prime}$ to the stop codon TAA for translation. Three $17 \beta$-HSD type 5 -specific PCR products were used for complete sequencing. We found differences with respect to the sequence of HAKRb (Qin et al. 1993): G instead of T (222nd nt), G instead of A (495th nt), G instead of $\mathrm{C}$ (702nd $\mathrm{nt})$, all of which do not alter the amino acid sequence. However, two additionally identified nucleotide substitutions resulted in amino acid changes; A instead of $\mathrm{G}$ (223rd nt) changing glutamic acid (75th amino acid) to lysine, and $G$ instead of C (525th nt) changing isoleucine (175th amino acid) to methionine (such as in all other members of the AKR1C family). Our sequencing data show $99 \cdot 5 \%$ homology to the CDS of HAKRb (Qin et al. 1993); 99.8\% homology was found to the sequence of a recombinant $3 \alpha-\mathrm{HSD}$ type 2 with 17ß-HSD activity (Lin et al. 1997), identified as 17 $\beta$-HSD type 5 (Penning 1999). Our sequence differed only in the 312th nt with $G$ (such as in the sequence of HAKRb) instead of $\mathrm{A}$, and in the 855th nt with $\mathrm{G}$ (such as in the sequences of PGFS and HAKRb) instead of $A$, both conserving the amino acid sequence of $17 \beta-$ HSD type 5 .

HAKRb (=3a-HSD) The expression of an enzyme structurally related to $3 \alpha-\mathrm{HSD}$ with a sequence according to clone HAKRb (Qin et al. 1993) with nearly the same genomic sequence found for $3 \alpha-\mathrm{HSD}$ type 2 (Khanna et al. 1995) was investigated by using a highly specific antisense primer (Table 1) ending $3^{\prime}$ with two unique nucleotides for HAKRb. The expected $248 \mathrm{bp}$ PCR product was not amplified in any of our kidney samples even at low-stringency annealing temperature for this 
specific primer. Therefore, an expression of an enzyme encoded by the sequence described by Qin et al. (1993) for $3 \alpha-H S D$ clone HAKRb could be excluded.

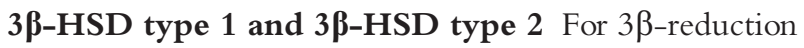
of the keto group in position 3 of steroids, the expressions
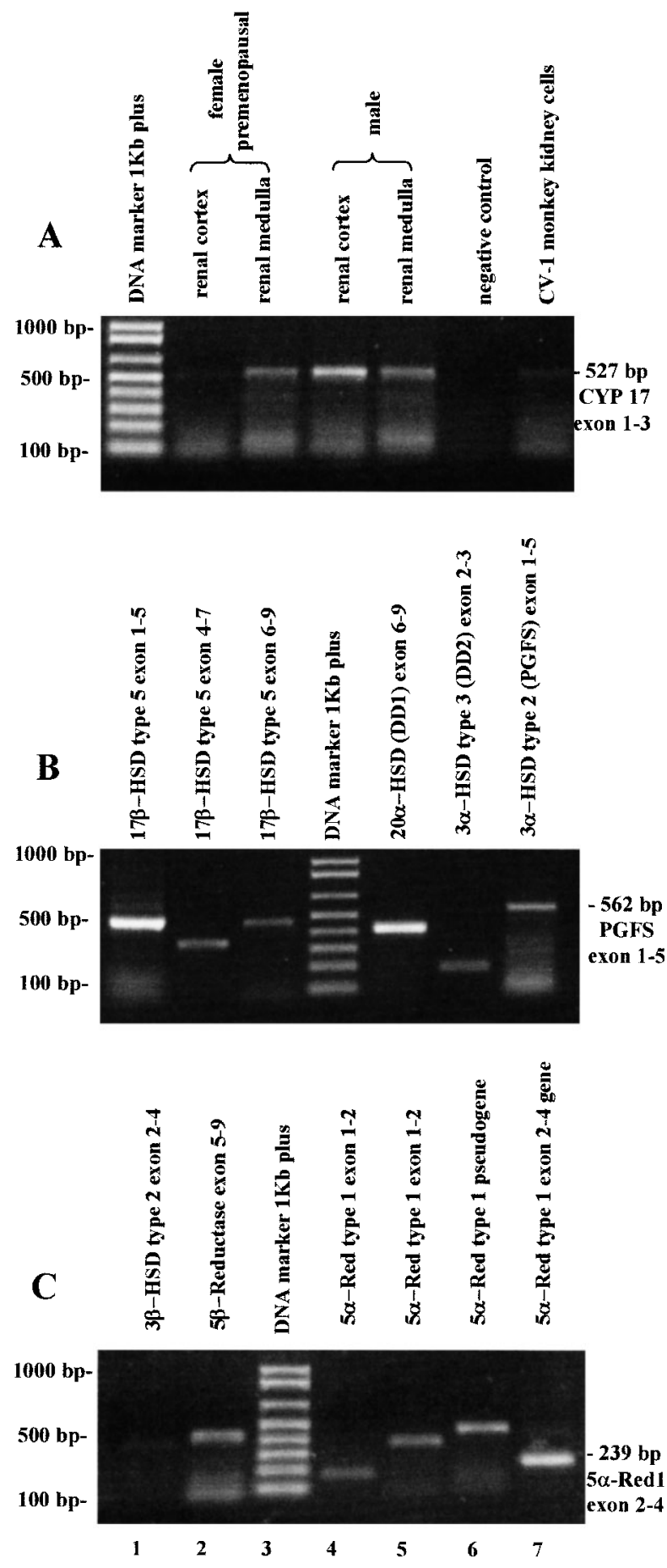

www.endocrinology.org of two different isoforms of the enzyme $3 \beta-\mathrm{HSD}$ were analysed with $3 \beta-H S D$ type $1-$ and $3 \beta-H S D$ type 2 -specific primer pairs (Table 1 ). Only PCR products with the expected size of $382 \mathrm{bp}$ for $3 \beta-\mathrm{HSD}$ type 2-specific amplification were obtained (Table 3). Sequencing of the re-extracted and reamplified PCR product (Fig. 5C) revealed 100\% homology to the sequence of 3 $\beta-\mathrm{HSD} /$ delta-4-delta-5 isomerase (Rheaume et al. 1991). Therefore, we conclude that only the isoform $3 \beta-\mathrm{HSD}$ type 2 is expressed in the human kidney, while the expression of $3 \beta$-HSD type 1 could not be detected in any of our kidney samples (Table 3 ).

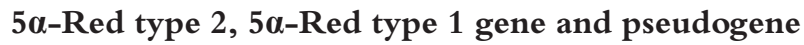
For ring A reduction of steroids, producing $5 \alpha-\mathrm{DH}$ metabolites, the expression of the reductases $5 \alpha$-Red type 1 and $5 \alpha$-Red type 2 was examined. $5 \alpha$-Red type 2-specific primers (Table 1 ) did not amplify the expected $244 \mathrm{bp}$ product from any renal sample (Table 3), but PCR with the specific primer pair for $5 \alpha$-Red type 1 (located in exon 1 and 2) resulted in amplification of the expected 168 bp PCR product with $99 \cdot 4 \%$ homology (Table 3) to the published sequence of the $5 \alpha$-Red-pseudogene (located on chromosome X) (Jenkins et al. 1991). There was only one nucleotide substitution: $G$ (gene-specific at this position) instead of A. According to the cDNA sequence (Andersson \& Russell 1990) from the gene of $5 \alpha$-Red type 1 (located on chromosome 5), our main

Figure 5 RT-PCR analysis for the expression of progesteronemetabolising enzymes. (A) 17 $\alpha$-hydroxylase (CYP17). cDNAs from premenopausal and male renal cortex and medulla and from CV-1 monkey kidney cells (control) were amplified in the first step with specific primers $17 \alpha$-hydroxylase sense and antisense. The negative control without cDNA did not give any staining while all kidney samples stained positively for the expected $527 \mathrm{bp}$ amplicon with a smear of smaller fragments. Therefore the DNA corresponding to the band of the correct size was re-extracted from the gel and reamplified for sequencing. (B) HSDs capable of $20 \alpha$-reduction. Three sets of primers were used for overlapping amplicons of $17 \beta-\mathrm{HSD}$ type 5 covering nearly the complete CDS and each one single primer pair for $20 \alpha$-HSD, 3 $\alpha$-HSD type 3, $3 \alpha$-HSD type 2. Specific PCRs were performed with cDNAs from female and male kidney cortex and medulla and CV-1 as well. Here premenopausal samples used for sequencing are shown. Three specific PCR products for $17 \alpha$-HDS type 5: amplicon 1 (exon 1-5) $476 \mathrm{bp}$, amplicon 2 (exon 4-7) $335 \mathrm{bp}$, and amplicon 3 (exon 6-9) $469 \mathrm{bp}$, each one single specific PCR products for

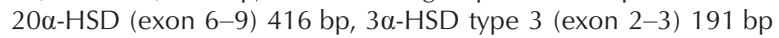

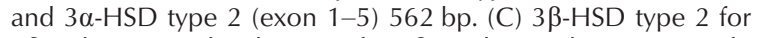
$3 \beta$-reduction and reductases for $5 \beta$ - and $5 \alpha$-reduction. Specific amplicons of cDNA samples from premenopausal kidney specimens used for sequencing are shown for $3 \beta$-HSD type 2 (exon 2-4) 382 bp (lane 1), 5ß-Red (exon 5-9) 451 bp (lane 2), DNA marker (100-1000 bp shown) (lane 3), 5 $\alpha$-Red type 1 (exon 1-2) 168 bp (lane 4), 5 $\alpha$-Red type 1 (exon 1-2 amplified with a sense primer located preATG) $351 \mathrm{bp}$ and/or $357 \mathrm{bp}$ for the gene and/or pseudogene transcript (lane 5), 5 $\alpha$-Red type 1 pseudogene-specific 454 bp (lane 6), and 5a-Red type 1 gene-specific (exon 2-4) 239 bp (lane 7). 
sequence revealed only 95.0\% homology (Table 3). In the chromatogram obtained by direct sequencing of the amplicon, additional underlying peaks of gene-specific nucleotides with lower concentration were also detectable at the positions of pseudogene-specific nucleotide substitutions. Therefore, in the sample of the premenopausal kidney cortex, mainly transcription of the pseudogene from chromosome $\mathrm{X}$ besides lower expression of the gene for $5 \alpha$-Red type 1 could be found. Because of this phenomenon, the PCR product from a male kidney medulla cDNA was sequenced additionally. In the direct sequencing data, $99.0 \%$ homology to the sequence of $5 \alpha$-Red type 1 gene (Table 3) was found with an underlying sequence of the pseudogene at lower levels. For analysing the region with six duplicated nucleotides in the pseudogene directly following the start codon ATG, the sense primer ( $5 \alpha$-Red type 1 preATG sense) located $5^{\prime}$ of the CDS matching both sequences and the antisense primer ( $5 \alpha$-Red type 1 antisense) were used for amplification. Sequencing of the PCR product from the premenopausal renal medulla (Fig. 5C, lane 5) again revealed high homologies (Table 3) to both the expected $351 \mathrm{bp}$ for gene-specific and $357 \mathrm{bp}$ for pseudogene-specific sequences (including the six additional nucleotides). Combination of the common sense primer ( $5 \alpha$-Red type 1 preATG sense) with a pseudogene-specific antisense primer ( $5 \alpha$-Red type 1 pseudo antisense) and further amplification of the PCR product in combining the same pseudogene-specific antisense primer with a pseudogenespecific sense primer ( $5 \alpha$-Red type 1 pseudo sense) by a second (semi-nested) PCR resulted in the expected $454 \mathrm{bp}$ product (Fig. 5C, lane 6). Sequencing of the amplified cDNA from the premenopausal renal medulla revealed a uniform sequence with 100\% homology for the pseudogene (Table 3) including the internal stop codon TGA unique to the pseudogene. Therefore, transcription of the pseudogene in the human kidney can be assumed, but translation would not result in a full-length protein because of premature termination. For analysing the $5 \alpha-$ Red type 1 gene expression, a gene-specific primer pair ending $3^{\prime}$ with nucleotides unique only to the gene (5a-Red type 1 gene sense and antisense) (Table 1) was used for amplification of a uniform PCR product. The amplified expected $239 \mathrm{bp}$ product (Fig. 5C, lane 7) was $100 \%$ homologous to the gene-specific sequence of 5a-Red type 1 (Andersson \& Russell 1990) (Table 3). Therefore, the expression of the isoform $5 \alpha$-Red type 1 was found in the human kidney, besides transcription of the pseudogene, while $5 \alpha$-Red type 2 expression could not be detected.

5及-Red (=AKR1D1) gene and pseudogene For the synthesis of $5 \beta$-reduced metabolites, expression analyses were performed for the enzyme $5 \beta$-Red (AKR1D1). PCR products of about $430-450 \mathrm{bp}$ using the primer pair $5 \beta$-Red sense and antisense (Table 1) were obtained (Fig.
5C). According to the sequence for the $5 \beta-$ Red cDNA (Kondo et al. 1994), an amplicon of 451 bp was expected. By direct sequencing we found 99.0\% homology (Table 3) to the sequence of the $5 \beta$-Red pseudogene (Charbonneau $\&$ The 2001) (reverse complement sequence located on chromosome 1), missing 19 nucleotides in the amplified cDNA of $432 \mathrm{bp}$ compared with $451 \mathrm{bp}$ from the $5 \beta$-Red gene transcript. To the $5 \beta$-Red gene cDNA sequence (Kondo et al. 1994) only 89.0\% homology was found (Table 3). Another direct sequencing from a sample of another female patient revealed highly homologous sequences specific for the pseudogene and the gene at the same time. Therefore, the transcription of the pseudogene and the expression of the enzyme $5 \beta$-Red was confirmed in the human kidney.

\section{Discussion}

This study examined mechanisms by which the MR may be protected against binding and antagonism of progesterone, which binds to the MR with the same or even higher affinity, but confers only little transcriptional activity (Rupprecht et al. 1993a, Myles \& Funder 1996). Therefore progesterone is assumed to be an MR antagonist. We found that progesterone has a higher antagonistic than agonistic function at the MR (Quinkler et al. 2002). It is still unclear how the mineralocorticoid function of aldosterone can be maintained especially at higher progesterone than aldosterone levels, e.g. during the luteal phase and pregnancy, when progesterone exceeds aldosterone concentrations 100-fold in the third trimester (Rosenthal et al. 1969).

One protective mechanism could be achieved by an additional binding site for progesterone in renal cells, e.g. the PR for high-specific progesterone binding, resulting in a sequestration of progesterone. This could enable binding of aldosterone to the MR. Therefore, we investigated the renal expression of the hPR. We found the expression of the hPR in kidney specimens from female (pre- and postmenopausal) and male patients in cortical as well as in medullary tissue preparations. The function of the receptor protein, tested in binding assays with the specific ligand R5020 and Scatchard plot analysis, revealed $K_{\mathrm{d}}$ values of about $0.8 \mathrm{nM}$ (mean of cortex and medulla) in kidney specimens compared with $0.98 \mathrm{nM}$ in the target tissue myometrium, consistent with the published $K_{\mathrm{d}}$ of $0.89 \mathrm{nM}$ for the myometrial hPR (Keightley 1979). These $K_{\mathrm{d}}$ values for binding of R 5020 characterise the same kind of receptor (hPR) in the myometrium and in the human kidney, supporting our hypothesis of renal hPR expression. The identity of the hPR was further tested by immunodetection. In tissue sections, a nuclear localisation of hPR was detected with the IgG monoclonal PgR 636 predominantly in epithelial cells of distal tubules, the mineralocorticoid target cells of the kidney. Western blots 
(differentiating $\mathrm{PR}-\mathrm{A}$ and $\mathrm{PR}-\mathrm{B}$ ) were performed for isoform analysis of $\mathrm{hPR}$ by immunodetection with the hPR-specific IgG1 monoclonal antibody NCL-PGR-312. A protein of about $117 \mathrm{kDa}$ corresponding to hPR-B (Sheridan et al. 1989, Kumar et al. 1998) was found in protein extracts from male and female kidney specimens, but a specific immunoreaction with a protein of the size corresponding to the isoform hPR-A (Kastner et al. 1990b) could not be shown. This is of special interest because $\mathrm{hPR}-\mathrm{A}$ is discussed as a co-repressor of hMR expression and function (McDonnell et al. 1994). Therefore a renal downregulation of hMR function by PR-A is not likely. In addition, our results of RT-PCRs from RNA of kidney cortex and medulla specimens from male and female patients and sequencing data with 100\% homology to hPR cDNA sequence (Misrahi et al. 1987), confirmed the identity of hPR and the renal transcription of the hPR gene. Therefore, the expression of hPR could be shown for the first time in the human kidney.

Renal progesterone-specific functions via hPR remain to be investigated. To date it is not known whether there is an additional influence on the mineralocorticoid function by a possibility of heterodimerisation, e.g. of hPR-B with the hMR co-localised in epithelial cells of distal tubules in the human kidney. Rather low levels of hPR in the kidney of postmenopausal origin were detected by Scatchard plot analyses, reflecting the mean of all cells in renal cortex or medulla. As only in a small number of cells was PR detected by immunohistology, especially in epithelia of distal tubules, local PR levels may be able to compete with $\mathrm{MR}$ for progesterone binding. Whether the expression of hPR would be raised in kidneys of premenopausal women by oestrogen for compensation of elevated progesterone could not be analysed because tissues from females during different cycle stages and/or pregnancy were not available. To discuss the role of the renal hPR for the hMR specificity, experiments investigating the number of both receptors and the co-localisation in renal cells would be helpful.

Additional mechanisms for protecting the hMR in the kidney against binding of progesterone appear to be essential. Another way of reducing progesterone binding to $\mathrm{MR}$ is the metabolism of progesterone to derivatives with lower affinity to the MR. More than $50 \%$ of progesterone is converted to $17 \alpha-\mathrm{OH}-\mathrm{P}, 20 \alpha-\mathrm{DH}-\mathrm{P}$, $17 \alpha-\mathrm{OH}, 20 \alpha-\mathrm{DH}-\mathrm{P}, \quad 5 \alpha-\mathrm{DH}-\mathrm{P}, \quad 5 \beta-\mathrm{DH}-\mathrm{P}, \quad 3 \beta, 5 \alpha-$ TH-P, $3 \alpha, 5 \alpha-\mathrm{TH}-\mathrm{P}, 3 \beta, 5 \beta-\mathrm{TH}-\mathrm{P}, 20 \alpha-\mathrm{DH}, 5 \alpha-\mathrm{DH}-\mathrm{P}$ and $20 \alpha-\mathrm{DH}, 3 \beta, 5 \alpha-\mathrm{TH}-\mathrm{P}$ in the human kidney (Quinkler et al. 1999, 2001). These metabolites exhibit reduced affinity to the MR depending on hydroxylated and/or reduced groups (Quinkler et al. 2002). For different pathways of progesterone metabolism (Fig. 6), we examined the expression of corresponding steroidconverting enzymes in the human kidney by RT-PCR.

Metabolism of progesterone to $17 \alpha-\mathrm{OH}-\mathrm{P}$ is achieved by $17 \alpha$-hydroxylase (CYP17). The expression of this

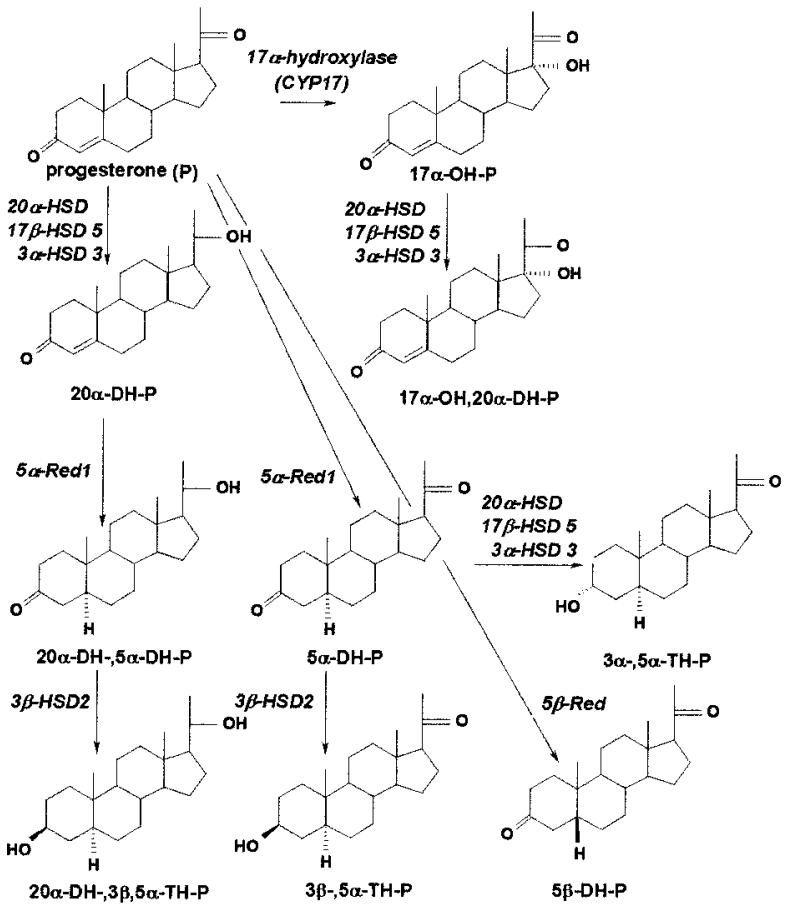

Figure 6 Scheme for progesterone metabolism with enzymes identified in the human kidney. Steroid-metabolising enzymes, confirmed by sequencing of RT-PCR products from human kidney specimens, are shown in different pathways of progesterone.

enzyme was found in renal cortex and medulla. One of 527 analysed nucleotides differed from the published sequence of exon 1 (Picado-Leonard \& Miller 1987) of the gene of CYP17, but this difference had been previously described by Chung et al. (1987). Therefore, in the kidney, hydroxylation by CYP17 of progesterone to $17 \alpha-\mathrm{OH}-\mathrm{P}$ with lower affinity to the hMR is likely. For the reduction of progesterone to $20 \alpha-\mathrm{DH}-\mathrm{P}$ we found the expression of different enzymes in our kidney

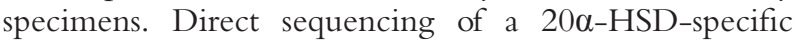
RT-PCR product from renal RNA preparations revealed $100 \%$ homology to the sequence for $20 \alpha-H S D$ (AKR1C1) (Nishizawa et al. 2000). By sequencing of three overlapping $17 \beta-\mathrm{HSD}$ type 5-specific amplicons covering nearly the complete CDS, we identified RNAs specific for the enzyme $17 \beta-H S D$ type 5 with a strong 20a-Red activity (Dufort et al. 1999). Amplification with a PGFS-specific sense primer resulted in a PCR product with 99.8\% homology to the published sequence (Suzuki-Yamamoto et al. 1999) for PGFS (AKR1C3). This amplicon contained identical sequences as obtained by the first $17 \beta-H S D$ type 5 -specific PCR. Comparison of the complete CDS of PGFS (AKR1C3) and the sequence of 3a-HSD type 2 (AKR1C3) transcript from chromosome 10p15-p14 (deduced from six published sequences in GeneBank accession No. 003739.2) exhibits about 
99.7\% homology. Our complete sequencing data of the CDS for $17 \beta-H S D$ type 5 reveal also $99 \cdot 7 \%$ homology to both AKR1C3 sequences described for PGFS and $3 \alpha$-HSD type 2 . Therefore we think that the sequence of the renal cDNA we found encodes $17 \beta-\mathrm{HSD}$ type 5 . It is probably the same enzyme as AKR1C3, as recently described (Penning et al. 2001). 3 $\alpha$-HSD type 3 (AKR1C2, DD2, BABP)-specific RNA with 100\% homology (Shiraishi et al. 1998) was also identified in our kidney specimens, but this enzyme shows only weak activity of $20 \alpha$-reduction. Therefore the enzymes $20 \alpha-$ HSD and $17 \beta-H S D$ type 5 are the main candidates for the $20 \alpha$-reduction of progesterone and $17 \alpha-\mathrm{OH}-\mathrm{P}$, while $3 \alpha-$ HSD type 3 may contribute to the $3 \alpha-$ reduction of $5 \alpha-$ DH-P to $3 \alpha, 5 \alpha-\mathrm{TH}-\mathrm{P}$ in the human kidney. $3 \beta$-Reduced progesterone metabolites are synthesised in the kidney by $3 \beta-H S D$ type 2 . The expression was found in renal cortex and medulla by RT-PCR with $100 \%$ homology to the published sequence (Rheaume et al. 1991). As 3B-HSD type 1 was not detected, the isoform $3 \beta$-HSD type 2 must be responsible for renal formation of $3 \beta, 5 \alpha-\mathrm{TH}-\mathrm{P}$. For synthesis of this metabolite and direct $5 \alpha$-reduction of progesterone, the expression of the isoform $5 \alpha$-Red type 1 was found in the kidney. The amplicon of gene-specific RT-PCR exhibits $100 \%$ sequence homology to the $5 \alpha-$ Red type 1 gene-specific CDS located on chromosome 5 (Andersson \& Russell 1990). Additionally a pseudogenespecific RT-PCR product reveals 100\% homology to the pseudogene with X-chromosomal location (Jenkins et al. 1991) as well. The role of the transcription of the intronless pseudogene (Mighell et al. 2000) with a stop codon in the region corresponding to the CDS, in the context of simultaneous gene expression, remains to be investigated. For the renal $5 \beta$-reduction of progesterone, we found the expression of the enzyme $5 \beta$-Red (AKR1D1) from the gene located on chromosome $7 \mathrm{q} 32-\mathrm{q} 33$ and also the transcription of the pseudogene located on chromosome 1 q23-q25 (reverse complement sequence) (Charbonneau \& The 2001) in the human kidney. There may be a regulatory role by transcription of the reverse complement sequence (antisense RNA) of $5 \beta$-Red gene on expression of the enzyme $5 \beta$-Red.

In conclusion, we produced evidence for two mechanisms for the mineralocorticoid function of aldosterone at the renal hMR in the presence of elevated progesterone. Binding of progesterone to the renal MR may be partly prevented by competitive binding to the $\mathrm{PR}$, and the concentration of free progesterone should be lowered by steroid-metabolising enzymes producing progesterone metabolites with reduced affinity to the MR in renal cells (Quinkler et al. 2002).

\section{Acknowledgements}

This work was supported by the grants DI $741 / 1-3$ and Graduierten-Kolleg 426/2-00 (Molekularbiologische
Grundlagen der Therapie) as well as 754 (Myokardiale Genexpression und Funktion, Myokardhypertrophie) from the Deutsche Forschungsgemeinschaft (DFG). We thank Katrin Kossatz-Eskandani for sequencing, Uschi Gruber for cell culture, Dr Alexandra Perez-Canto for histological inspection, Dr Ronald Evans for providing the plasmid pRShMR, and Dr Wiebke Arlt for putting at our disposal cDNAs from adrenals and testes.

\section{References}

Andersson S \& Russell DW 1990 Structural and biochemical properties of cloned and expressed human and rat steroid 5 alpha-reductases. PNAS 87 3640-3644.

Andersson S, Berman DM, Jenkins EP \& Russell DW 1991 Deletion of steroid 5 alpha-reductase 2 gene in male pseudohermaphroditism. Nature 354 159-161.

Arcuri F, Sestini S, Ricci C, Runci Y, Carducci A, Paulesu L \& Cintorino M 2000 Progestin regulation of 11 beta-hydroxysteroid dehydrogenase expression in T-47D human breast cancer cells. Journal of Steroid Biochemistry and Molecular Biology 72 239-247.

Arriza JL, Weinberger C, Cerelli G, Glaser TM, Handelin BL, Housman DE \& Evans RM 1987 Cloning of human mineralocorticoid receptor complementary DNA: structural and functional kinship with the glucocorticoid receptor. Science 237 268-275.

Attia GR, Zeitoun K, Edwards D, Johns A, Carr BR \& Bulun SE 2000 Progesterone receptor isoform A but not B is expressed in endometriosis. Journal of Clinical Endocrinology and Metabolism $\mathbf{8 5}$ 2897-2902.

Batra S \& Iosif S 1985 Progesterone receptors in human vaginal tissue. American Journal of Obstetrics and Gynecology 153 524-528.

Beato M, Arnemann J, Chalepakis G, Slater E \& Willmann T 1987 Gene regulation by steroid hormones. Journal of Steroid Biochemistry 27 9-14.

Bergeron C, Ferenczy A, Toft DO, Schneider W \& Shyamala G 1988 Immunocytochemical study of progesterone receptors in the human endometrium during the menstrual cycle. Laboratory Investigation $\mathbf{5 9}$ $862-869$.

Charbonneau A \& The VL 2001 Genomic organization of a human 5 beta-reductase and its pseudogene and substrate selectivity of the expressed enzyme. Biochimica et Biophysica Acta 1517 228-235.

Chung BC, Picado Leonard J, Haniu M, Bienkowski M, Hall PF, Shively JE \& Miller WL 1987 Cytochrome P450c17 (steroid 17 alpha-hydroxylase/17,20 lyase): cloning of human adrenal and testis cDNAs indicates the same gene is expressed in both tissues. PNAS 84 407-411.

Ciaccio PJ \& Tew KD 1994 cDNA and deduced amino acid sequence of a human colon dihydrodiol dehydrogenase. Biochimica et Biophysica Acta 1186 129-132.

Duffy DM \& Stouffer RL 1995 Progesterone receptor messenger ribonucleic acid in the primate corpus luteum during the menstrual cycle: possible regulation by progesterone. Endocrinology 136 1869-1876.

Dufort I, Rheault P, Huang X-F, Soucy P \& Luu-The V 1999 Characteristics of a highly labile human type 517 betahydroxysteroid dehydrogenase. Endocrinology 140 568-574.

Dumont M, Van LT, Dupont E, Pelletier G \& Labrie F 1992 Characterization, expression, and immunohistochemical localization of 3 beta-hydroxysteroid dehydrogenase/delta 5 -delta 4 isomerase in human skin. Journal of Investigative Dermatology 99 415-421.

Edwards CR, Stewart PM, Burt D, Brett L, McIntyre MA, Sutanto WS, de Kloet ER \& Monder C 1988 Localisation of 11 betahydroxysteroid dehydrogenase - tissue specific protector of the mineralocorticoid receptor. Lancet 2 986-989. 
Gao J, Mazella J, Tang M \& Tseng L 2000 Ligand-activated progesterone receptor isoform $\mathrm{hPR}-\mathrm{A}$ is a stronger transactivator than hPR-B for the expression of IGFBP-1 (insulin-like growth factor binding protein-1) in human endometrial stromal cells. Molecular Endocrinology 14 1954-1961.

Geller DS, Farhi A, Pinkerton N, Fradley M, Moritz M, Spitzer A, Meinke G, Tsai FT, Sigler PB \& Lifton RP 2000 Activating mineralocorticoid receptor mutation in hypertension exacerbated by pregnancy. Science 289 119-123.

Graham JD \& Clarke CL 1997 Physiological action of progesterone in target tissues. Endocrine Reviews 18 502-519.

Herrmann SM, Funke-Kaiser H, Schmidt-Petersen K, Nicaud V, Gautier-Bertrand M, Evans A, Kee F, Arveiler D, Morrison C, Orzechowski HD et al. 2001 Characterization of polymorphic structure of cathepsin $G$ gene: role in cardiovascular and cerebrovascular diseases. Arteriosclerosis, Thrombosis and Vascular Biology 21 1538-1543.

Horwitz KB \& Alexander PS 1983 In situ photolinked nuclear progesterone receptors of human breast cancer cells: subunit molecular weights after transformation and translocation. Endocrinology 113 2195-2201.

Horwitz KB \& McGuire WL 1975 Specific progesterone receptors in human breast cancer. Steroids 25 497-505.

Jenkins EP, Hsieh CL, Milatovich A, Normington K, Berman DM, Francke U \& Russell DW 1991 Characterization and chromosomal mapping of a human steroid 5 alpha-reductase gene and pseudogene and mapping of the mouse homologue. Genomics 11 1102-1112.

Johansson ED \& Jonasson LE 1971 Progesterone levels in amniotic fluid and plasma from women. I. Levels during normal pregnancy. Acta Obstetrica et Gynecologica Scandinavica 50 339-343.

Jose M, Puche C, Cabero A, Cabero L \& Meseguer A 1999 Expression of P450c17 messenger ribonucleic acid in postmenopausal human ovary tissues. Fertility and Sterility $\mathbf{7 1}$ $528-535$.

Kastner P, Krust A, Turcotte B, Stropp U, Tora L, Gronemeyer H \& Chambon P 1990a Two distinct estrogen-regulated promoters generate transcripts encoding the two functionally different human progesterone receptor forms A and B. EMBO Journal 9 1603-1614.

Kastner P, Bocquel MT, Turcotte B, Garnier JM, Horwitz KB, Chambon P \& Gronemeyer H $1990 b$ Transient expression of human and chicken progesterone receptors does not support alternative translational initiation from a single mRNA as the mechanism generating two receptor isoforms. Journal of Biological Chemistry $26512163-12167$.

Kato J, Onouchi T \& Okinaga S 1978 Hypothalamic and hypophysial progesterone receptors: estrogen-priming effect, differential localization, 5 alpha-dihydroprogesterone binding, and nuclear receptors. Journal of Steroid Biochemistry 9 419-427.

Keightley DD 1979 The binding of progesterone, R-5020 and OR G-2058 to progesterone receptor. European Journal of Cancer 15 785-790.

Kester HA, van der Leede BM, Van der Saag PT \& van der Burg B 1997 Novel progesterone target genes identified by an improved differential display technique suggest that progestin-induced growth inhibition of breast cancer cells coincides with enhancement of differentiation. Journal of Biological Chemistry 272 16637-16643.

Khanna M, Qin K-N, Wang RW \& Cheng K-C 1995 Substrate specificity, gene structure, and tissue-specific distribution of multiple human 3 alpha-hydroxysteroid dehydrogenases. Journal of Biological Chemistry 270 20162-20168.

Kondo K-H, Kai M-H, Setoguchi Y, Eggertsen G, Sjöblom P, Setoguchi T, Okuda K-I \& Björkhem I 1994 Cloning and expression of cDNA of human delta 4-3-oxosteroid 5 betareductase and substrate specificity of the expressed enzyme. European Journal of Biochemistry 219 357-363.

Kumar NS, Richer J, Owen G, Litman E, Horwitz KB \& Leslie KK 1998 Selective down-regulation of progesterone receptor isoform B in poorly differentiated human endometrial cancer cells: implications for unopposed estrogen action. Cancer Research $\mathbf{5 8}$ 1860-1865.

Labrie F, Sugimoto Y, Luu-The V, Simard J, Lachance Y, Bachvarov D, Leblanc G, Durocher F \& Paquet N 1992 Structure of human type II 5 alpha-reductase gene. Endocrinology 131 1571-1573.

Lachance Y, Luu-The V, Labrie C, Simard J, Dumont M, de Launoit Y, Guerin S, Leblanc G \& Labrie F 1990 Characterization of human 3 beta-hydroxysteroid dehydrogenase/delta 5-delta 4-isomerase gene and its expression in mammalian cells [published erratum appears in Journal of Biological Chemistry 1992267 3551]. Journal of Biological Chemistry 265 20469-20475.

Lachance Y, Luu The V, Verreault H, Dumont M, Rheaume E, Leblanc G \& Labrie F 1991 Structure of the human type II 3 beta-hydroxysteroid dehydrogenase/delta 5 -delta 4 isomerase ( 3 beta-HSD) gene: adrenal and gonadal specificity. DNA and Cell Biology 10 701-711.

Lin H-K, Jez JM, Schlegel BP, Peehl DM, Pachter JA \& Penning TM 1997 Expression and characterization of recombinant type 2 3 alpha-hydroxysteroid dehydrogenase (HSD) from human prostate: demonstration of bifunctional 3 alpha/17 beta-HSD activity and cellular distribution. Molecular Endocrinology 11 1971-1984.

Lou H, Hammond L, Sharma V, Sparkes RS, Lusis AJ \& Stolz A 1994 Genomic organization and chromosomal localization of a novel human hepatic dihydrodiol dehydrogenase with high affinity bile acid binding. Journal of Biological Chemistry $\mathbf{2 6 9}$ 8416-8422.

McDonnell DP, Shahbaz MM, Vegeto E \& Goldman ME 1994 The human progesterone receptor A-form functions as a transcriptional modulator of mineralocorticoid receptor transcriptional activity. Journal of Steroid Biochemistry and Molecular Biology 48 425-432.

Mighell AJ, Smith NR, Robinson PA \& Markham AF 2000 Vertebrate pseudogenes. FEBS Letters 468 109-114.

Misao R, Nakanishi Y, Fujimoto J \& Tamaya T 1998 Steroid receptor mRNA levels in human corpus luteum. Hormone Research $\mathbf{5 0}$ 155-159.

Misrahi M, Atger M, d'Auriol L, Loosfelt H, Meriel C, Fridlansky F, Guiochon-Mantel A, Galibert F \& Milgrom E 1987 Complete amino acid sequence of the human progesterone receptor deduced from cloned cDNA. Biochemical and Biophysical Research Communications 143 740-748.

Misrahi M, Venencie PY, Saugier-Veber P, Sar S, Dessen P \& Milgrom E 1993 Structure of the human progesterone receptor gene. Biochimica et Biophysica Acta 1216 289-292.

Monder C \& Lakshmi V 1989 Evidence for kinetically distinct forms of corticosteroid 11 beta-dehydrogenase in rat liver microsomes. Journal of Steroid Biochemistry 32 77-83.

Mulac-Jericevic B, Mullinax RA, DeMayo FJ, Lydon JP \& Connely OM 2000 Subgroup of reproductive functions of progesterone mediated by progesterone receptor-B isoform [In Process Citation]. Science 289 1751-1754.

Myles K \& Funder JW 1996 Progesterone binding to mineralocorticoid receptors: in vitro and in vivo studies. American Journal of Physiology 270 E601-E607.

Nishizawa M, Nakajima T, Yasuda K, Kanzaki H, Sasaguri K, Watanabe K \& Ito S 2000 Close kinship of human 20 alphahydroxysteroid dehydrogenase gene with three aldo-keto reductase genes. Genes to Cells 5 111-125.

Nolten WE, Lindheimer MD, Oparil S \& Ehrlich EN 1978 Desoxycorticosterone in normal pregnancy. I. Sequential studies of the secretory patterns of desoxycorticosterone, aldosterone, and cortisol. American Journal of Obstetrics and Gynecology 132 414-420.

Oelkers WK 1996 Effects of estrogens and progestogens on the renin-aldosterone system and blood pressure. Steroids 61 166-171.

Penning TM 1999 Molecular determinants of steroid recognition and catalysis in aldo-keto reductases. Lessons from 3 alphahydroxysteroid dehydrogenase. Journal of Steroid Biochemistry and Molecular Biology 69 211-225. 
Penning TM, Burczynski ME, Jez JM, Lin HK, Ma H, Moore M, Ratnam K \& Palackal N 2001 Structure-function aspects and inhibitor design of type 517 beta-hydroxysteroid dehydrogenase (AKR1C3). Molecular and Cellular Endocrinology 171 137-149.

Picado Leonard J \& Miller WL 1987 Cloning and sequence of the human gene for P450c17 (steroid 17 alpha-hydroxylase/17,20 lyase): similarity with the gene for P450c21. DNA 6 439-448.

Pollow K, Juchem M, Grill HJ, Manz B, Beier S, Henderson D, Schmidt-Gollwitzer K \& Elger W 1989 3H-ZK 98,734, a new 11 beta-aryl substituted antigestagen: binding characteristics to receptor and serum proteins. Contraception 40 213-232.

Pratt WB \& Toft DO 1997 Steroid receptor interactions with heat shock protein and immunophilin chaperones. Endocrine Reviews $\mathbf{1 8}$ 306-360.

Qin K-N, New MI \& Cheng K-C 1993 Molecular cloning of multiple cDNAs encoding human enzymes structurally related to 3 alpha-hydroxysteroid dehydrogenase. Journal of Steroid Biochemistry and Molecular Biology 46 673-679.

Quinkler M, Johanssen S, Grossmann C, Bähr V, Müller M, Oelkers W \& Diederich S 1999 Progesterone metabolism in the human kidney and inhibition of 11 beta-hydroxysteroid dehydrogenase type 2 by progesterone and its metabolites. Journal of Clinical Endocrinology and Metabolism 84 4165-4171.

Quinkler M, Johanssen S, Bumke-Vogt C, Oelkers W, Bahr V \& Diederich S 2001 Enzyme-mediated protection of the mineralocorticoid receptor against progesterone in the human kidney. Molecular and Cellular Endocrinology 171 21-24.

Quinkler M, Meyer B, Bumke-Vogt C, Grossmann C, Gruber U, Oelkers W, Diederich S \& Bahr V 2002 Agonistic and antagonistic properties of progesterone metabolites at the human mineralocorticoid receptor. European Journal of Endocrinology 146 789-799.

Rheaume E, Lachance Y, Zhao HF, Breton N, Dumont M, de Launoit Y, Trudel C, Luu The V, Simard J \& Labrie F 1991 Structure and expression of a new complementary DNA encoding the almost exclusive 3 beta-hydroxysteroid dehydrogenase/delta 5-delta 4-isomerase in human adrenals and gonads. Molecular Endocrinology 5 1147-1157.

Rosenthal HE, Slaunwhite WR \& Sandberg AA 1969 Transcortin: a corticosteroid-binding protein of plasma. X. Cortisol and progesterone interplay and unbound levels of these steroids in pregnancy. Journal of Clinical Endocrinology 29 352-367.
Rupprecht R, Arriza JL, Spengler D, Reul JM, Evans RM, Holsboer F \& Damm K 1993a Transactivation and synergistic properties of the mineralocorticoid receptor: relationship to the glucocorticoid receptor. Molecular Endocrinology 7 597-603.

Rupprecht R, Reul JM, van Steensel B, Spengler D, Soder M, Berning B, Holsboer F \& Damm K 1993 b Pharmacological and functional characterization of human mineralocorticoid and glucocorticoid receptor ligands. European Journal of Pharmacology 247 145-154.

Sasano H, Frost AR, Saitoh R, Matsunaga G, Nagura H, Krozowski ZS \& Silverberg SG 1997 Localization of mineralocorticoid receptor and 11 beta-hydroxysteroid dehydrogenase type II in human breast and its disorders. Anticancer Research 17 2001-2007.

Sheridan PL, Evans RM \& Horwitz KB 1989 Phosphotryptic peptide analysis of human progesterone receptor. New phosphorylated sites formed in nuclei after hormone treatment. Journal of Biological Chemistry 264 6520-6528.

Shiraishi H, Ishikura S, Matsuura K, Deyashiki Y, Ninomiya M, Sakai S \& Hara A 1998 Sequence of the cDNA of a human dihydrodiol dehydrogenase isoform (AKR1C2) and tissue distribution of its mRNA. Biochemical Journal 334 399-405.

Stolz A, Hammond L, Lou H, Takikawa H, Ronk M \& Shivley JE 1993 cDNA cloning and expression of the human hepatic bile acid-binding protein. Journal of Biological Chemistry 268 10448-10457.

Suzuki-Yamamoto T, Nishizawa M, Fukui M, Okuda-Ashitaka E, Nakajima T, Ito S \& Watanabe K 1999 cDNA cloning, expression and characterization of human prostaglandin $\mathrm{F}$ synthase. FEBS Letters 462 335-340.

Topper YJ \& Freeman CS 1980 Multiple hormone interactions in the developmental biology of the mammary gland. Physiological Reviews 60 1049-1106.

Tsai MJ \& O'Malley BW 1994 Molecular mechanisms of action of steroid/thyroid receptor superfamily members. Annual Review of Biochemistry 63 451-486.

Williams SP \& Sigler PB 1998 Atomic structure of progesterone complexed with its receptor. Nature 393 392-396.

Received 24 April 2002

Accepted 29 July 2002 